\title{
Lise Öğrencilerinin ve Öğretmen Adaylarının Atmosfer Basıncını, Etkileyen Faktörleri ve illişkili Günlük Hayat Problemlerini Açıklayabilme Durumlarının incelenmesi
}

\section{Investigation of High School Students' and Teacher Candidates' Explanations Regarding Atmospheric Pressure, Factors Affecting It and Related Daily Life Problems}

\section{Eda DEMIRHAN}

İsmail ÖNDER ${ }^{* *}$

\section{Şenol BEŞOLUK ${ }^{\star \star \star}$}

Öz. Öğrencilerin, soyut kavramların yoğun olduğu fen konularını iyi anlaması için konuyla ilgili temel bilgileri çok iyi kavraması ve birbirleri ile ilişkilendirilerek doğru bir biçimde yapılandırması gerekir. Açık hava basıncı bu konulardan birisidir ve anlaşılabilmesi için öğrencilerin çok sayıda kavramı iyi bilmesi ve bunları ilişkilendirebilmesi gerekir. Bu ilişkiler iyi kurulmadığı takdirde öğrenciler konuyu teorik olarak kavramada, ilişkili günlük hayat problemlerini anlamada ve bu olayları bilimsel olarak açıklamada zorluk yaşayacaklardır. Bu nedenle bu çalışmada lise öğrencilerinin ve öğretmen adaylarının atmosfer basıncını, onu etkileyen faktörleri ve ilişkili günlük hayat problemlerini açıklayabilme durumlarının belirlenmesi ve lise öğrencileri, fen bilimleri, kimya ve fizik öğretmen adaylarının konuya ilişkin açıklama ve tanımlarının ne ölçüde farklılaştığının belirlenmesi amaçlanmıştır. Bu amaç doğrultusunda araştırma, genel tarama modellerinden tekil tarama modeli ile yürütülmüştür. Araştırmanın katıımcılarını lise, fen bilgisi öğretmenliği, kimya ve fizik öğretmenliği son sınıf öğrencileri oluşturmaktadır. Araştırmada veri toplama aracı olarak bir adet açık uçlu ve sekiz adet iki aşamalı soru içeren bir form kullanılmıştır. Araştırmanın sonuçları katılımcıların açık hava basıncını, onu etkileyen unsurları ve ilişkili olayları açıklamakta çoğunlukla yetersiz kaldıklarını ve açıklamalarında bilimsel bilgiler ile çelişen önemli düzeyde ve çok sayıda hatanın bulunduğunu göstermiştir. Ayrıca, katılımcıların eğitim seviyeleri ve alanlarına göre soruları doğru yanıtlama oranlarının önemli ölçüde farklılaşmadığı görülmüştür.

Anahtar Kelimeler: Atmosfer basıncı, açık hava basıncı, kavramsal anlama, günlük hayat problemleri.

Abstract. Students should have basic information about science topics which are abstract in general and should construct concepts correctly associating with each other in order to better understand the science subjects. Atmospheric pressure is one of these issues so students should know many concepts and should relate them in order to well understand atmospheric pressure. Unless these relationships are well established, students will have difficulty in grasping theoretical subjects, understanding the problems associated with everyday life and explaining these events scientifically. Therefore, in this study, it was aimed to determine high school students' and teacher candidates' explanations of atmospheric pressure, factors affecting it and related daily life problems and to what extend explanations of high school students and teacher candidates differ. The research was carried out with a survey method. Participants of the research are senior high school students and senior science, chemistry and physics teacher candidates. A form containing one open-ended and eight two-tiered questions, was used as data collection tool. The results of the study showed that participants were often inadequate to explain the concept of atmospheric pressure, the factors that affected it and the associated events, and there were significant and numerous mistakes in participants descriptions that are in conflict with scientific knowledge. In addition, in terms of education levels and majors, there were no significant differences in correct answer rates of the questions.

Keywords: Atmospheric pressure, air pressure, conceptual understanding, daily life problems.

\section{Toplumsal Mesaj.}

Çalışmada lise öğrencilerinin ve öğretmen adaylarının atmosfer basıncını, onu etkileyen faktörleri ve ilişkili günlük hayat problemlerini açıklayabilme durumlarının belirlenmesi ve lise öğrencileri, fen bilimleri, kimya ve fizik öğretmen adaylarının konuya ilişkin açıklama ve tanımlarının ne ölçüde farklılaştığının belirlenmesi amaçlanmıştır. Sonuç olarak, katılımcıların yanıtlarının açık hava basıncını açıklamakta çoğunlukla yetersiz olduğu ve eğitim seviyeleri açısından doğru yanıtlama oranlarının ciddi olarak farklılaşmadığı bulunmuştur.

Public Interest Statement. In the present study, positive and negative sides of the process of teacher candidate training were discussed according to the views of teacher candidates and other stakeholders. Half of the administrators agree that teacher candidates can choose a different city from where they have been appointed to; however, the other half disagree on that issue. Additionally, while most of the consulting teachers disapprove of this practice, more than half of the teacher candidates approve it.

\footnotetext{
*Yrd. Doç. Dr., Sakarya Üniversitesi, Eğitim Fakültesi, Özel Eğitim Bölümü, edemirhan@sakarya.edu.tr

${ }^{* *}$ Doç. Dr., Sakarya Üniversitesi, Eğitim Fakültesi, Matematik ve Fen Bilimleri Eğitimi Bölümü, ionder@sakarya.edu.tr

*** Doç. Dr., Sakarya Üniversitesi, Eğitim Fakültesi, Matematik ve Fen Bilimleri Bölümü, sbesoluk@sakarya.edu.tr
} 


\section{GiRiş}

Fen bilimleri, bireylerin dünyayı algılamalarına çevrelerinde karşılaştıkları olayları/durumları açıklayabilmelerine ve geleceğe yönelik öngörülerde bulunabilmelerine yardımcı olan açıklama ve tanımlamalarda bulunmaktadır (De Jong ve Talanquer, 2015). Okullarda fen bilimlerinin öğretilmesinin amaçlarından bir tanesi de fen ile ilişkili olaylar hakkında bireylerin karar verme ve problem çözme süreçlerine dâhil olmasıdır (Leite ve Afonso, 2004). Bunun için de bireylerin fen bilimlerini anlamalarını ve ilişkili durum/olay/olguları açıklayabilmelerini gerekli kılmaktadır. Ancak birçok araştırma öğrencilerin fen bilimleri ile ilişkili olay/olgu ve kavramları anlamada ve açıklamada güçlükler yaşadığını göstermektedir (Doymuş, Canpolat, Bayrakçeken ve Gürses, 1998; Birinci-Konur ve Ayas, 2010; Demircioğlu, Tütüncü ve Demircioğlu, 2016). Bu sorunların çeşitli nedenleri olmakla birlikte temel nedenin fen bilimlerinin karmaşık ve soyut yapıda anlatılması ve açıklanması olduğu söylenebilir (Gabel, 1999). Öğrencilerin anlamlı öğrenmeler gerçekleştirmeleri için öncelikle onların ne bildiklerini ve bu bilgileri nasıl yapılandırdıklarını bilmemiz gerekmektedir (Lin, Cheng ve Lawrenz, 2000). Bu da ancak öğretim faaliyetlerinde öğrencilerin kavramsal öğrenmelerini nasıl gerçekleştirdiğinin tespiti ile mümkün olacaktır.

Öğrencilerin fen bilimlerine ilişkin kavramları öğrenebilmesi için öğretmenlerin öncelikle o kavram hakkındaki öğrenci açıklamalarını alması ve bu açıklamalar doğrultusunda kavramın öğretimini planlaması gerekmektedir (Barke, Hazari ve Yitbarek, 2009). Mevcut bilgilerin yeni öğrenmelerle ilişkilendirilmemesi kavramsal öğrenmenin anlamlı olmasını ve kalıcılığını etkileyecektir. Öğretmenler, öğrenci açıklamalarından yola çıkarak fen kavramlarının makro, submikro ve sembolik yapısını da göz önünde bulundurarak öğrenme ortamlarını düzenlemelidir (Barke, Hazari ve Yitbarek, 2009). Ancak, birçok çalışma öğretmenlerin fen kavramlarının öğretiminde bu boyutlardan farklı düzeylerde yararlanmasına karşııı bu boyutların hep birlikte anlamlı öğrenme için göz önünde bulundurulmadığını tespit etmiştir (Savec, Sajovic ve Wissiak Grm, 2009; Treagust ve Chandrasegaran, 2009; Koç, 2014). Bu durum ilişkisiz birçok bilgi parçacı̆̆ının öğrencilerde oluşması ve öğrenmenin anlamlı olmamasına sebep olmakta (Gabel, 1999) ve öğrencilerin karşılaştıkları fen olay ve olgularını anlamalarını ve ilişkili günlük hayat problemlerini açıklamalarını güçleştirmektedir.

Öğrencilerin kavramsal öğrenmelerinin tespitinde genellikle hesaplamaya dayanan ve matematiksel işlem gerektiren soruların kullanıldığı görülmektedir (Lin, Cheng ve Lawrenz, 2000). $\mathrm{Bu}$ durum öğrencilerin matematiksel işlemlere odaklanmasını ve kavramın tam anlamıla anlaşılmasını engellemektedir (Bodner, 1991; Gabel, 1999). Matematiksel işlem sorularının yanında öğretmenlerin fen kavramlarını ve kavramlar arasındaki ilişkileri açıklamaya yönelik sorular da kullanmaları gerekmektedir. Nurrenbern ve Pickering (1987) sadece matematiksel işlem gerektiren sorularda öğrenci başarısının yüksek olmasına rağmen kavramsal açıklamalar gerektiren sorularda başarı düzeyinin oldukça düşük olduğunu ifade etmiştir. Ayrıca Lin, Cheng ve Lawrenz (2000), lise öğrencilerinin ve öğretmenlerinin gaz kanunlarını anlama seviyelerini araştırdığı çalışmada çalışmaya katılan öğrencilerin \%80'inin kavramsal problemlerin çözümünde yetersiz kaldığını ve problemleri doğru çözebilmek için matematiksel çözümlere başvurduklarını bulmuştur. Öğretimdeki matematiksel işlem gerektiren soruların kullanılmasına benzer bir eğilim ders kitaplarında da mevcuttur. De Berg (1989) 14 kimya kitabını incelediği çalışmasında basınç-hacim ilişkisine yönelik 80 alıştırmadan sadece 5 tanesinin nitel kavramsal açıklama gerektiren türde olduğunu ifade etmiştir. De Berg (1995) matematiksel işlem gerektiren sorulara bağımlılı̆ın açıklama gerektiren soruların kullanılmasıyla azalacağını ve bu durumun kavramsal öğrenmeyi destekleyeceğini vurgulamaktadır. Benzer şekilde Nakiboğlu ve Yıldırır (2011) kavramsal öğrenmeleri destekleyecek farklı türde soruların kitap yazımı ve derslerin işlenişinde kullanılmasını önermektedirler.

Fen bilimlerinde yer alan birçok kavram kendi disiplininde önemli olmanın yanı sıra diğer disiplinler için de önemlidir. Bireyler herhangi bir disiplinde yer alan bir kavramı iyi yapılandıramamışlarsa o 
disipline ilişkin olay/olgu/durumu açıklamada sıkıntı yaşamalarının yanında diğer disiplinlerde ilişkili olay/durum ve olguların açıklanmasında daha çok sıkıntı yaşayacakları aşikârdır. Oysa kavramlar iyi yapılandırılsa ve disiplinler arası ilişkiler kurulabilse ilgili kavramlar daha iyi öğrenilebilecektir. Atmosfer basıncı bu disiplinler arası özelliğe sahip kavramlardan biri olup günlük hayatta sıklıkla karşılaştığımız bir olgudur. Nefes alıp vermek, pipetle bir şeyler içmek, bir parfümü sıkmak, uçakların türbülansa girmesi, rüzgârların ve yağışların oluşumu gibi olayların nasıl gerçekleştiğinin bilimsel olarak açıklanabilmesi için açık hava basıncının iyi bilinmesi gerekmektedir. Yukarıda belirtilen örnek olaylar ve bunlar gibi pek çok olayda da görülebileceği gibi atmosfer basıncı fizik, kimya, biyoloji, coğrafya ve mühendislik konularının bir kısmı ile doğrudan ilişkili olup bu konuların öğretilmesinde en önemli unsur olan öğretmenlerin kavramsal anlamalarının yeterli olması gerekmektedir.

Atmosfer basıncını ve onu etkileyen değişkenleri anlayabilmek için öncelikle kütle, kuvvet, ağırlık, basınç, hacim, kütlesel çekim, ısı, sıcaklık, özısı, mol kütlesi, alan, nem, yükselti, ivme, moment, akışkanlık, derişim ve özkütle gibi temel kavramları bilmek gerekmektedir ve bu kavramlardaki eksik ya da hatalı bilgiler açık hava basıncının anlaşılmasında güçlük çekilmesine neden olmaktadır (Basca ve Grotzer, 2001; Kariotoglou ve Psillos,1993; Önen, 2005; Psillos ve Kariotoglou, 1999; Raghavan, Sartoris, ve Glaser, 1998; Sere, 1982; Tytler, 1998). Katı ve sıvılardaki basınç konuları öğrenciler tarafından somut olarak gözlemlenebilmesine karşın, atmosfer basıncı ve gazlar soyut bir konu olduğu için öğrencilerin öğrenmede güçlük çektiği ve zihinlerinde doğru yapılandıramadıkları görülmektedir (Sadıç, 2017; Aksoy, 2003; Akşit, 2011; Ayas, Karataş ve Coştu, 2003; Mas, Perez ve Harris, 1987; Nelson, Aron ve Francek, 1992; Şahin, 2001). Ayrıca atmosfer basıncı ve atmosfer basıncını etkileyen faktörlerin açıklamalarına ders kitaplarında katı, sıvı ve kapalı kaplardaki gaz basıncı konularına göre çok daha az yer verildiği görülmektedir. Bunun yanı sıra ders kitaplarında atmosfer basıncının tam ve açık tanımına, yükseklik, sıcaklık ve nem oranı ile ilişkisine yönelik yeterli açıklamalara çok nadir rastlanmaktadır.

Gaz basınc konusu ortaokul 7 ve 8. sınıf fen bilimleri dersi; lisede 10. sınıf fizik dersi, 9 ve 11. sınıf kimya dersi ve 9 ve 10 sınıf coğrafya dersleri programlarında yer almaktadır. Fen bilimleri öğretmenliği, fizik ve kimya lisans programlarında ise genel fizik ve genel kimya dersleri içeriğinde yer aldığı görülmektedir. Ortaokul, lise ve üniversite ders kitaplarında atmosfer basıncı konusunun açıklanması Evangelista Torricelli'nin deneyi üzerinden yapılmakta ve atmosfer basıncının cıvalı barometre ile ölçüldüğü belirtilmektedir. Öğrencilerin Torricelli deneyini iyi anlayabilmeleri için öncelikle sıvı basıncını iyi anlamış olmalarının yanı sıra akışkan olmaları nedeniyle gazların ve sıvıların uyguladığı basıncın her yönde etki ettiğini de kavramaları gerekmektedir. Benzer şekilde kapalı kaplardaki gazların basıncının ölçümü ile ilişkili açıklamalarda ve örnek sorularda genellikle açık uçlu ve kapalı uçlu manometre şekilleri çizilerek açıklamalar yapılmaktadır. Kapalı bir kaptak gazın basıncı açık uçlu manometre ile ölçüldüğünde kaptaki basıncın atmosfer basıncına göre değeri belirlenir. Bu ve benzeri birçok durumda öğrenciler genellikle atmosfer basıncının sayısal değeri ile uğraşırken onun gerçekte tam olarak nasıl oluştuğunu ve nelere bağlı olarak değiştiğini bilmemekte ve bu durumla ilgilenmemektedirler. Lise ve üniversite seviyesinde atmosfer basıncından daha çok kapalı kaplardaki gaz basıncı konusuna ve kinetik teoriye yer veriliyor olması ve ayrımın yeterince yapılmaması öğrencilerin atmosfer basıncı ve onunla ilgili faktörleri açıklarken kapalı kaplardaki gaz basıncı ile karıştırmalarına neden olmaktadır (Hacioglu, Durukan ve Cigdem, 2016). Ayrıca ders kitaplarında basınç konusu ile ilgili yetersiz ve hataya sevk edecek açıklamaların yurt içinde ve yurt dşında birçok araştırmada ortaya konulduğu görülmektedir (Şahin, 2001; Aksoy, 2003; Ayas, Karataş ve Çoştu 2003; Nakiboğlu ve Yıldırır, 2011; Gillette ve Sanger, 2014). Bunun yanı sıra ders kitaplarındaki açık hava basıncı ile ilgili sorular incelendiğinde diğer konulara benzer şekilde bu konu ile ilgili kavramlar arası ilişkileri açıklamayı içeren sorular yerine matematiksel işlem içerikli soruların bulunduğu görülmektedir (Nakiboğlu ve Poyraz, 2004; Nakiboğlu ve Yıldırır, 2011). 
Illköğretim seviyesinden itibaren birçok farklı ders ve konuda karşımıza çıkan atmosfer basıncı kavramının tam ve doğru anlaşılmadığını ve ilköğretim 4. sınıftan itibaren farklı sınıf ve kademedeki öğrencilerde ve öğretmen adaylarında kavram yanılgılarının var olduğunu ifade eden çalışmalar bulunmaktadır (Nakiboğlu ve Özkılıç-Arik, 2006; Novick ve Nussbaum, 1978; Stavy, 1988; Lin, Cheng ve Lawrenz, 2000; Mas, Perez ve Harris, 1987; Yalçınkaya ve Boz, 2015). Ancak bu çalışmalarda atmosfer basıncının tanımı, atmosfer basıncını etkileyen faktörlerin neler olduğu ve nasıl etkilediği ve günlük hayat problemleri ile ilişkisine birlikte yer veren ve konuya ilişkin alanlarda eğitim alan öğretmen adaylarında durumu sorgulayan bir çalışma yer almamaktadır. Bunun yanı sıra fen bilgisi, fizik ve kimya öğretmen adayları ve lise öğrencileriyle bu konuda birlikte yürütülen çalışma da bulunmamaktadır. Fen bilimleri, fizik ve kimya öğretmen adayları alanları gereği üniversite eğitiminde açık hava basıncıyla ilişkili çeşitli dersler almaktadırlar ve ileride mesleklerini yürütürken bu konu ile sıklıkla karşılaşacaklardır. Dolayısıyla aldıkları eğitimin konuyu kavrama düzeylerini önemli ölçüde etkilemesi beklenmektedir. Bu nedenle lise öğrencilerinden ne derecede farklılaştıkları bu beklentinin ne ölçüde gerçekleştiği hakkında fikir verecektir. Bu nedenle bu çalışmada lise öğrencilerinin ve öğretmen adaylarının atmosfer basıncını, onu etkileyen faktörleri ve ilişkili günlük hayat problemlerini açıklayabilme durumlarının belirlenmesi ve lise öğrencileri, fen bilimleri, kimya ve fizik öğretmen adaylarının konuya ilişkin açıklama ve tanımlarının ne ölçüde farklılaştığının belirlenmesi amaçlanmıştır.

\section{YÖNTEM}

Bu araştırmada genel tarama modellerinden tekil tarama modeli ile yürütülmüştür. Tekil tarama modeli'nde geçmişte ya da halen var olan bir durumu var olduğu şekliyle betimlemeyi amaçlanmaktadır (Karasar, 2012). Bu çalışmada lise son sınıf öğrencilerinin ve öğretmen adaylarının açık hava basıncı ve onu etkileyen unsurlara ilişkin kavramsal anlamalarının belirlenmesi amaçlandığından tekil tarama modeline uymaktadır.

\subsection{Katılımcılar}

Araştırmanın katılımcılarını; bir anadolu lisesinin 12. sınıfında öğrenim gören 70 öğrenci, Eğitim Fakültesinde öğrenim gören 77 fen bilgisi öğretmenliği son sınıf öğrencisi ile 23 kimya ve 30 fizik öğretmenliği son sınıf öğrencisi olmak üzere toplam 200 öğrenci oluşturmaktadır. Belirtilen branşlardaki öğretmen adayları çalışma konusu ile ilgili çeşitli fizik ve kimya dersleri aldıkları için katılımcı olarak araştırmaya dahil edilmişlerdir. Öğrenciler araştırmaya gönüllü olarak katılmışlardır.

\subsection{Verilerin Toplanması}

Araştırmada veri toplama aracı olarak bir adet açık uçlu ve sekiz adet iki aşamalı soru içeren bir form kullanıımıştır (Bkz. EK1). Bu form, araştırmacılar tarafından geliştirilmiştir ve kapsam geçerliliğini sağlamak için fizik, kimya, biyoloji ve fen bilimleri olmak üzere dört alan uzman tarafından incelenmiştir. Alan uzmanlarının dönütleri doğrultusunda gerekli düzeltmeler yapılarak formun son hali oluşturulmuştur. Sorular, açık hava basıncı ve bunu etkileyen faktörleri bilmeye ve bu konuya ilişkin çeşitli problem durumlarını açıklamaya yöneliktir. íki aşamalı sorularda öğrencilerden sorunun ilk kısmında verilen üç seçenekten birini işaretlemeleri ve ikinci kısmında ise seçtikleri seçeneğin neden ya da nedenlerini açıklamaları istenmiştir. Katılımcılara soruları cevaplandırmaları için intiyaç duydukları süre verilmiştir. Veriler, araştırmacılar tarafından sınıf ortamında toplanmıştır.

\subsection{Verilerin Analizi}

Birinci soruya ilişkin toplanan verilerin ve iki aşamalı soruların açıklamalarının değerlendirilmesi Nas ve Çepni (2016) ve Abraham, Grzybowski, Renner ve Marek (1992) nin çalışmalarındaki kategoriler dikkate alınarak yapılmıştır. Bu kategoriler, "tam anlama, kısmi anlama, yanlış kavrama ile birlikte kısmi anlama, yanlış kavrama ve anlamama" şeklindedir. iki aşamalı soruların değerlendirilmesinde ise öncelikte sorunun birinci aşaması Doğru Seçenek (DS), Yanlış Seçenek (YS) 
ve Boş (B) olmak üzere üç kategori altında analiz edilmiştir. Soruların ikinci aşaması olan "nedenleri" kısmından elde edilen cevapların nitel analizi için ise Tablo 1'deki kategoriler kullanılmıştır. İlgili kategoriler ve açıklamaları Tablo 1'de belirtilmektedir.

Tablo 1. Soruların Analizinde Kullanılan Kategoriler ve ıçerikleri

\begin{tabular}{|c|c|}
\hline Anlama Düzeyi & Kategoriye ilişkin açıklama \\
\hline Tam anlama (TA) & $\begin{array}{l}\text { Geçerliliği olan cevabın tüm bileşenlerini içeren ve tam ya da } \\
\text { tama yakın doğru açıklamalarla ifade edilen cevaplar. }\end{array}$ \\
\hline Kısmi Anlama (KA) & $\begin{array}{l}\text { Geçerli olan cevabın bir bölümünü içeren ancak hatalı bilgi } \\
\text { içermeyen eksik açıklamalarla ifade edilen cevaplar. }\end{array}$ \\
\hline $\begin{array}{l}\text { Yanlış kavrama ile birlikte } \\
\text { kısmi anlama (YKA) }\end{array}$ & $\begin{array}{l}\text { Geçerli olan cevabın bazı yönlerini içeren fakat doğru } \\
\text { açıklamaların yanı sıra bazı yanlış açıklamaları da içeren cevaplar }\end{array}$ \\
\hline Yanlış kavrama (YK) & $\begin{array}{l}\text { Tamamı bilimsel olmayan bilgi ya da bilgilerden oluşan } \\
\text { açıklamalar }\end{array}$ \\
\hline Anlamama (A) & $\begin{array}{l}\text { Boş bırakma, bilmiyorum, anlamadım şeklindeki veya soruyu } \\
\text { aynen tekrarlama, ilgisiz/anlaşımayan cevaplar. }\end{array}$ \\
\hline
\end{tabular}

Katıımcıların yanıtları fen eğitimi alanında uzman iki araştırmacı tarafından ayrı ayrı analiz edilmiştir. Uyuşmazlık durumunda ise araştırmacılar bir araya gelerek ortak karara varmışlardır. Araştırmacılar arası tutarlık 0,87 bulunmuştur. Her bir soru için kategoriler bazında frekanslar verilmiştir. Bununla birlikte güvenirliği arttırmak ve katılımcıların bakış açılarını örneklendirmek için her bir kategoriye ilişkin katılımcıların ifadelerinden doğrudan alıntılar sunulmuştur. Doğrudan alıntılar L, FBÖ, KÖ ve FÖ simgeleriyle ve öğrencilerin sıra numarası dikkate alınarak gösterilmiştir. $L$, lise öğrencilerini; FBÖ, fen bilgisi öğretmen adaylarını; KÖ, kimya öğretmen adaylarını ve FÖ, ise fizik öğretmen adaylarını belirtmektedir. Örneğin; L11, onbir numaralı lise öğrencisini; FBÖ24, ise yirmi dört numaralı fen bilgisi öğretmen adayını; KÖ5, beş numaralı kimya öğretmen adayını; FÖ8 ise sekiz numaralı fizik öğretmen adayını belirtmektedir.

\subsection{Açık hava basıncı ve etkileyen faktörler}

Basınç konusunun işlendiği fen bilgisi lise ve üniversite fizik ve kimya kitaplarında çoğunlukla açık hava basıncı ile ilgili yeterli düzeyde bilgiye rastlanmamaktadır. Bu nedenle veri toplama aracındaki soruların daha kolay anlaşılabilmesi için özet düzeyde bilgi sunulma intiyacı duyulmuştur.

\subsubsection{Açık hava basıncı}

Yeri çevreleyen atmosfer insanlar için en önemli gaz basıncı kaynağıdır. Biz ve çevremizdekiler önemli bir basınç uygulayan hava denizinin içinde genellikle dibine yakın yaşıyoruz. Atmosferdeki gazlar yerçekiminden dolayı aşağı yönlü bir kuvvet ve dolayısıyla açık hava basıncı ya da atmosfer basıncı olarak tanımlanan bir basınç uygular. Herhangi bir maddenin uyguladığı kuvvet, kütlesi $(\mathrm{m})$ ile onun ivmesinin çarpımına (a) eşittir ( $F=m . a)$. Yerçekimi kuvveti $9,8 \mathrm{~m} / \mathrm{s}^{2}$ lik bir ivme uygular ve 1 $\mathrm{m}^{2}$ kesit alana sahip, atmosfer boyunca uzanan bir hava kolonu yaklaşık olarak 10.000 kg'ık bir kütleye sahiptir. Dolayısıyla bu hava kolonunun uygulayacağı kuvvet:

$\mathrm{F}=10.000 \mathrm{~kg} \times 9,8 \mathrm{~m} / \mathrm{s}^{2}=1 \times 105 \mathrm{~kg} \cdot \mathrm{m} / \mathrm{s}^{2}=1 \times 105 \mathrm{~N}$

Söz konusu hava kolonunun uyguladığı basınç $(P)$, kuvvetin kesit alanı $(A)$ ile bölümüne eşittir.

$\mathrm{P}=\mathrm{F} / \mathrm{A}=1 \times 105 \mathrm{~N} / \mathrm{m}^{2}=1 \times 105 \mathrm{~Pa}=1 \times 102 \mathrm{kPa}$

Deniz seviyesindeki atmosferik basıncın yaklaşık 100 kPa olduğu görülmekle birlikte belli bir yerde kesin atmosferik basınç sıcaklık, deniz seviyesinden yüksekliğe ve hava koşullarına bağlıdır." (Brown, LeMay, Bursten ve Brunauer, 1994: 345; Wallace ve Hobbs; 2006). Açık hava basıncı ve bunun ölçümü genellikle Toricelli deneyi üzerinden yani cıvalı barometre ile anlatıldığından deniz seviyesinde ortalama açık hava basıncı 760 mm yüksekliğinde bir cıva kolonunu dengeleyen basınç olarak ifade edilir ve bu değer 1 atmosfer (atm) olarak tanımlanır.

Standart atmosfer basıncı Pascal olarak tanımlandığında; 1 atm $=101.325 \mathrm{~Pa}=101,325 \mathrm{kPa}$ 
Ayrıca $1 \mathrm{~mm}$ yüksekliğinde civanın basıncına eş değer basınç 1 torr olarak isimlendirilir. Böylelikle; $1 \mathrm{~atm}=76 \mathrm{cmHg}=760 \mathrm{mmHg}=760$ torr $=101,325 \mathrm{kPa}=101.325 \mathrm{~N} / \mathrm{m}^{2}$ olur (Mortimer, 1979: 187188).

Ancak atmosfer basıncının herhangi bir anda bulunulan yerde, genellikle tam olarak bu standart değerde olmayacağı, sıcaklık, yükselti, yerçekimi, nem ve hava olayları gibi dinamik etmenlere bağlı olduğu unutulmamalıdır (Bueche ve Jerde, 2003: 272).

\subsubsection{Açık hava basıncına etki eden etmenler}

1. Sıcaklık: Sıcaklık arttığında ısınan hava genleşir ve yoğunluğu azalır. Dolayısıyla birim hacimdeki havanın ağırlığı azalır ve bunun sonucunda açık hava basıncı da azalır. Bunun tam tersi sıcaklık azaldığında olur. Sıcaklık; bulunulan konumun enlemine, dünyanın eksen eğikliğine ve günlük hareketlerine bağlı olarak değiştiği için bu değişkenler atmosfer basıncının da değişimine neden olur (Pidwirny, 2016: 3). Ekvator çevresinde ısınmaya bağlı olarak termik alçak basınç, kutuplarda ise soğumaya bağı olarak termik yüksek basınç oluşur. Eksen eğikliği güneş ışınlarının geliş açısını yıl boyunca etkiler. Bunun yanı sıra karaların ve denizlerin özısıları farkı olduğundan yıl boyunca sıcaklıkları arasındaki fark değişir. Karaların özısısı daha küçük olduğundan yazın daha çabuk ısınır ve denizlere göre basınçları daha düşük olur. Kışları ise karalar daha çabuk soğuduğu için üzerlerinde denizlere göre daha alçak hava basıncı oluşur (Wallace ve Hobbs, 2006). Karaların ve denizlerin yıl içinde olduğu gibi gün içinde de farklı hızda ısınma ve soğuma özellikleri vardır. Bu nedenle karalar ve denizler üzerindeki sıcaklık ve bunlar arasındaki sıcaklık farkı gün boyunca değişir ve tersyüz olur. Bun sonucunda da kara ve denizler üzerindeki atmosfer basıncı gün içinde farklıık gösterir. Gündüz karalar daha sıcak olduğu için alçak basınç alanı oluştururken gece denizler daha sıcak olduğu için alçak basınç alanı oluşturur. Bu da deniz kıyılarında gündüz ve gece meltemlerinin oluşmasına yol açar. Bu da gündüzleri deniz meltemi oluşumuna, geceleri ise kara meltemi oluşumuna yol açar. (Pidwirny, 2016: 18). Dağların çabuk ısınması eteklerindeki vadilerin ise daha geç ısınması sebebi ile oluşan basınç farklılığı ise dağ meltemi ve vadi meltemine yol açar. Gündüz vadi meltemi gece ise dağ meltemine yol açar.

2. Yükselti ve yer çekimi: Bir yere etki eden hava kütlesinin kalınlığı ve yoğunluğu ne kadar fazla ise gaz kütlesi ve dolayısıyla atmosfer basıncı o kadar fazla olur. Atmosfer basıncı atmosferin kalınlığına bağıı olarak yer yüzeyine yakın olan kısımlarda daha fazla yükseklerde daha azdır. Yükseldikçe hava katmanının kalınlı̆ındaki azalma yükseklikle doğru orantılı değildir. Yükseklik arttıkça yerçekimi kuvveti azaldığı için gazların yoğunluğu azalmakta ve bunun sonucu olarak atmosfer basıncı da azalmaktadır. Yükseklik arttıkça atmosfer basıncındaki azalma önce hızı daha sonra ise yavaş gerçekleşmektedir (Bueche ve Jerde, 2003; Gettys, Keller ve Skove, 1995: 402-403). Yer yüzeyinden $20 \mathrm{~km}$ yükseklikte atmosferin yoğunluğu deniz seviyesindeki değerinin yaklaşık \%8'ine düşer (Bueche ve Jerde, 2003). Atmosferdeki gazların toplamının yaklaşık yarısı deniz seviyesi ile 5,5 km lik yükseklik arasındaki bölgede bulunur. Atmosfer gazlarının tümünün toplam kütlesinin yaklaşık \% 99.9 ‘u deniz seviyesi ile 48 km’lik yükseklik arasında bulunur (Jacobson, 2005).

3. Nem: Su buharının molekül kütlesi atmosferin temel iki bileşeni olan oksijen ve azot moleküllerinin her ikisinin de molekül kütlelerinden düşüktür. Dolayısıyla havada su buharı derişiminin artması atmosfer basıncını düşürecektir. Bu durum çok genel ve yanlış bir kanı olan nemli havanın kuru havadan ağır olması görüşü ile çelişmektedir (Pidwirny, 2016: 3).

4. Dinamik etmenler: Dünyanın kendi ekseni etrafındaki dönüşü, atmosferin dönüşünü farklı enlemler üzerinde farklı hareketlere zorlar. Dolayısıyla bazı enlemlerde alçak basınç oluştururken bazılarında yüksek basınç oluşturur. Sub-polar bölgelerde alçak basınç alanları ve sub-tropik bölgelerde de yüksek basınç alanlarının oluşumu dünyanın kendi ekseni etrafında dönüşünden kaynaklanmaktadır (Pidwirny, 2016). 


\section{BULGULAR}

Çalışmaya dahi edilen her bir grubun "Açık hava basıncını tanımlayınız." sorusuna ilişkin yanıtlarının frekans ve yüzde değerleri Tablo 2'de belirtilmiştir.

Tablo 2. Katıımcıların Açık Hava Basıncının Tanımına İlişkin Verdikleri Cevapların Eğitim Seviyeleri ve Alanlarına Göre Frekansları

\begin{tabular}{llllll}
\hline & TA & KA & YKA & YK & A \\
& $f(\%)$ & $f(\%)$ & $f(\%)$ & $f(\%)$ & $f(\%)$ \\
\hline L & $3(4.3)$ & $9(12.9)$ & $17(24.3)$ & $5(7.1)$ & $36(51.4)$ \\
FBÖ & $3(3.9)$ & $16(20.8)$ & $28(36.4)$ & $15(19.5)$ & $15(19.5)$ \\
KÖ & $1(4.3)$ & $6(26.1)$ & $9(39.1)$ & $4(17.4)$ & $3(13.0)$ \\
FÖ & $2(6.7)$ & $7(23.3)$ & $15(50.0)$ & $5(16.7)$ & $1(3.3)$ \\
Toplam & $9(4.5)$ & $38(19.0)$ & $69(34.5)$ & $29(14.5)$ & $55(27.5)$ \\
\hline
\end{tabular}

Tablo 2 incelendiğinde katılımcıların verdikleri yanıtların toplam 69 kişi ile en çok YKA kategorisinde ve 55 kişi ile A kategorisinde yer aldığı görülmektedir. Eğitim seviyelerine göre baktığımızda ise son sınıf fen bilgisi öğretmen adayları ile lise son sınıf öğrencilerinin yanıtlarının çoğunlukla YKA ve A kategorilerinde toplandığı görülmektedir. Farklı eğitim seviye ve alanlardaki katılımcıların her bir kategoriye ilişkin yanıtları aşağıda örneklendirilmiştir.

L57- Atmosferdeki gazların yerçekimi etkisi ile ağırlıklarından dolayı yaptıkları basınçtır.

L67- Havada bulunan gazların ağırlığından dolayı uyguladığı basınca denir.

FBÖ38- Atmosferde var olan havanın ağırlığından ileri gelen basınçtır.

KÖ6-Deniz seviyesinden atmosferin dışına kadar olan aradaki gazların ağırlı̆ıından dolayı

TA yapmış olduğu basınçtır.

FÖ7- Belli bir alana havanın içerisindeki gazların ağırlıkları sebebiyle uyguladığı basınçtır.

FÖ14- Atmosferde bulunan gaz taneciklerinin yer çekimi etkisiyle yeryüzüne ve yeryüzünde bulunan cisimlere yaptı basınçtır.

L17- Yeryüzündeki varlıklara etki eden atmosfer gazlarının basıncına açık hava basıncı denir FBÖ2- Açık hava basıncı havanın cisimlere uyguladığı basınçtır.

KÖ1- Açık bir kap düşünün. Bu kabın içine giren havanın kaba yaptı̆̆ı basınçtır

KÖ9- Havada bulunan gazların yapmış olduğu basınçtır.

KA FÖ1- Havada bulunan gaz taneciklerinin yaptığı basınçtır.

L31- Açık havanın cisimler üzerinde oluşturduğu basınçtır. Deniz seviyesinde $76 \mathrm{~cm} / \mathrm{Hg}^{\prime} \mathrm{dir}$

L68- Atmosferdeki gazların yeryüzüne yaptığı basınçtır.

KÖ15- Havanın içerisinde bulunan gazların yoğunluğundan dolayı oluşan basınca denir.

FBÖ7-Deniz seviyesinden yukarılara çıkıldıkça azalan, havanın yoğunluğundan dolayı uyguladığı basınçtır.

YKA KÖ19-Açık hava basıncı $76 \mathrm{cmHg}$ dir.

L14- Deniz seviyesinde civa dolu kaba konan borunun içindeki sıvının kaç "cm" yükselmesidir.

L64- Havadaki gaz moleküllerinin etkileşimi, hareketi sonucunda oluşan basınçtır.

FÖ25- Deniz seviyesinde havanın yaptığı basınca denir. $76 \mathrm{cmHg}$ dir.

L69- Açık hava basıncı bir sıvının üstündeki gazların uyguladığı basınca denir.

L6- Gökyüzünde olan havanın eşit olan gazlar bütünlüğüne denir.

YK L5- Nem ile havanın yeryüzüne veya gökyüzüne çıkması.

KÖ17- Deniz seviyesinden yukarılara çıkıldıkça havadaki gazların oluşturduğu basınçtır.

KÖ4- Cisim üzerine uygulanan kuvvet Po ile ifade edilir.

FÖ23- Havadaki gazların sahip olduğu basınçtır. 
İkinci soru olan "Havadaki nem oranı arttığında açık hava basıncı nasıl değişir? Cevabınızın neden(ler)ini açıklayınız" sorusuna katılımcıların verdikleri yanıtlar Tablo 3'de belirtilmiştir.

Tablo 3. Katılımcıların Havadaki Nem Oranının Açık Hava Basıncına Etkisine Illişkin Verdikleri Cevapların Eğitim Seviyelerine ve Alanlarına Göre Frekansları

\begin{tabular}{|c|c|c|c|c|c|c|c|c|c|c|}
\hline & $\begin{array}{l}\text { DS- } \\
\text { TA } \\
\text { f(\%) }\end{array}$ & DS-KA & $\begin{array}{l}\text { DS- } \\
\text { YKA } \\
\text { f (\%) }\end{array}$ & DS-YK & DS-A & $\begin{array}{l}\text { YS- } \\
\text { KA }\end{array}$ & $\begin{array}{l}\text { YS- } \\
\text { YKA } \\
\text { f (\%) }\end{array}$ & YS-YK & YS-A & B-A \\
\hline L & - & - & $2(2.9)$ & $2(2.9)$ & $7(10.0)$ & - & - & $19(27.1)$ & $28(40.0)$ & $12(17.1)$ \\
\hline FBÖ & - & $1(1.3)$ & - & 2 (2.6) & $5(6.5)$ & - & - & $47(61.0)$ & $20(26.0)$ & $2(2.6)$ \\
\hline KÖ & - & - & - & & $3(13.0)$ & & $2(8.7)$ & $10(43.5)$ & $8(34.8)$ & - \\
\hline FÖ & - & - & - & & $4(13.3)$ & - & & $16(53.3)$ & $8(26.7)$ & $2(6.7)$ \\
\hline Toplam & - & $1(0.5)$ & $2(1.0)$ & $4(2.0)$ & 19(9.5) & - & $2(1.0)$ & $92(46.0)$ & $64(32.0)$ & $16(8.0)$ \\
\hline
\end{tabular}

Açık hava basıncına nemin etkisine ilişkin soruya DS-TA kategorisinde yanıt veren öğrenci bulunmazken, DS-KA kategorisinde sadece kimya öğretmenliğinden bir öğrencinin bulunduğu görülmektedir. Bununla birlikte katılımcıların genel olarak bu soruda yanlış seçeneği seçtikleri ve eğitim seviyeleri ve alanları fark etmeksizin bu konuda yanlış kavramalarının olduğu görülmektedir. Buna göre katılımcıların nemin açık hava basıncına etkilerine ilişkin verdikleri yanıtların nedenlerine ilişkin örnekler aşağıda sunulmuştur.

FBÖ5- Nem oranı artınca havadaki gaz oranı azalacak ve gaz basıncı da azalacaktır.

L64- Nemin artması sıcaklığın artması anlamına gelir. Sıcaklık arttıkça gaz molekülleri daha hızlı hareket eder. Hız arttıkça basınç azalır.

L63- Çünkü nem buharlaşma sonucu oluşur, yani gaz olur. Açık hava basıncı gazların yaptığı basınç olduğundan artar.

FBÖ2- Açık hava basıncı artar. Çünkü havada bulunan tanecik sayısı artacağından bu taneciklerin insanlar üzerinde uygulayacağı ağırlıktan dolayı basınç artacaktır.

YKA FBÖ27- Nemli hava daha ağırdır bu yüzden daha fazla basınç uygular.

KÖ2- Nem yani su buharı molekülleri artar ve molekül sayısı artınca diğer değiş̧kenler sabit olursa tabi ki basınç artar (P.V=n.R.T)

KÖ5- Artan nem havanın yoğunluğunun artmasına dolayısıyla açık hava basıncının artmasina neden olur.

L39- Açık hava basıncı sadece yükseklik ile değişir

L41- nem oranı arttıkça sıcaklık artar. Sıcaklık arttıkça basınçta artar.

YK L43-Çünkü nem sıcaklıktan dolayı meydana gelir. Sıcaklığın da etkisi yoktur.

FÖ3- Nemli hava bunaltıcı olur. Hava sıcakken nem oranı artar. Dolayısıyla basınç da artar.

FÖ18- Çünkü nem açık hava basıncını etkilemez.

$A$

KÖ21- nem oranın artması su buharı moleküllerinin artmasına sebep olur. Bu da açık hava basıncını azaltır.

Katılımcıların "Deniz seviyesinden yukarılara çıktıkça açık hava basıncı nasıl değişir? Cevabınızın neden(ler)ini açıklayınız" sorusuna verdikleri yanıtlar Tablo 4'de belirtilmiştir.

Tablo 4. Katılımcıların Yüksekliğin Açık Hava Basıncına Etkisine İlişkin Verdikleri Cevapların Eğitim

\begin{tabular}{|c|c|c|c|c|c|c|c|c|c|c|c|}
\hline \multicolumn{12}{|c|}{ Seviyelerine ve Alanlarına Göre Frekansları } \\
\hline & DS-TA & & DS-KA & DS- & DS-YK & DS-A & YS- & YS- & YS-YK & YS-A & B-A \\
\hline & & & & YKA & & & KA & YKA & & & \\
\hline & & $\mathrm{f}$ & $f(\%)$ & $f(\%)$ & $f(\%)$ & $f(\%)$ & $f(\%)$ & $f(\%)$ & $f(\%)$ & $f(\%)$ & $f(\%)$ \\
\hline & (\%) & & & & & & & & & & \\
\hline L & $2(2.9)$ & & 18(25.7) & $4(5.7)$ & $1(1.4)$ & $38(54.3)$ & - & - & - & 6(8.6) & $1(1.4)$ \\
\hline FBÖ & $8(10.4)$ & & $18(23.4)$ & $3(3.9)$ & 3(3.9) & $25(32.5)$ & - & $2(2.6)$ & $7(9.1)$ & $11(14.3)$ & - \\
\hline KÖ & $3(13.0)$ & & 8(34.8) & - & - & $8(34.8)$ & - & - & $3(13.0)$ & $1(4.3)$ & - \\
\hline FÖ & $3(10.0)$ & & $6(20.0)$ & - & 1(3.3) & $8(26.7)$ & - & - & $2(6.7)$ & $10(33.3)$ & - \\
\hline Toplam & $16(8.0)$ & & $50(25.0)$ & $7(3.5)$ & $5(2.5)$ & $79(39.5)$ & - & $2(1.0)$ & $12(6.0)$ & $28(14.0)$ & $1(0.5)$ \\
\hline
\end{tabular}


Tablo 4'e bakıldığında katılımcıların büyük bir çoğunluğunun bu soruda doğru seçeneği işaretlediği belirlenmiş olup, yanıtlarının çoğunlukla DS-A ve DS-KA kategorilerinde toplandığı görülmektedir. Yanlış seçeneği işaretleyen katılımcıların yanıtlarının ise çoğunlukla YS-A kategorisinde bulunduğu tespit edilmiştir. Aşağıda öğrencilerin yanıtlarının nedenlerine ilişkin açıklamalar ilgili kategoriler çerçevesinde sunulmuştur.

FÖ14- Atmosferde bulunan gaz taneciklerinin yer çekimi etkisiyle yeryüzüne ve yeryüzünde bulunan cisimlere yaptı basınçtır. Yukarılara doğru çıkıldıkça üstte kalan ağırlık azalacağı için açık hava basıncı azalır.

TA basınç da azalır.

L46- Yukarı çıkıldıkça yukarıdaki gaz miktarı azalır, her gazın bir ağırlığı olduğundan dolayı L63- Gazların ağırlıkları vardır. Yerçekimi nedeni ile aşağı doğru inerler. Hafif gazlar yukarıda kalır ve yukarıdaki gazların yoğunluğu azdır. Bu nedenle azalır.

KÖ7- Yukarılara çıktıkça hava kütlesi azaldığı için dolayısıyla basınçta azalır.

L48- Gazların yoğunluğu nedeni ile deniz seviyesinde en çok yukarılarda en azdır.

FBÖ41- Çünkü yukarılara çıktıkça havanın yoğunluğu azalır ve daha az sayıda olan hava moleküllerinin basıncı aşağıdan daha düşüktür

FBÖ12- azalır çünkü üzerimize gelen gaz sütununun miktarı azalır. Daha az gaz üzerimize

KA basınç yaptığı için açık hava basıncı azalır.

L47- birim kütle azaldığından basınçta azalır.

FBÖ3- Çünkü yükseklere çıkıldıkça hava miktarı azalır.

FBÖ37-havanın yoğunluğu azalır

FÖ6-birim hava miktarı azalır.

YKA L38-02 gazı azaldığı için Po azalır. Gazların basıncı mol sayısıyla doğru orantıııdır.

FBÖ11- Yukarılara çıktıkça atmosferde bulunan gaz miktarı artar. Buna bağlı olarak basınçta artar.

FBÖ18- Yükseklere çıktıkça açık hava basıncı artar. Bu yüzden su yükseklere çıkılıkça daha düşük sıcaklıkta kaynar.

KÖ18- Yukarı çıkıldıkça O2 miktarı artar, dundan dolayı hissedilen basınç artar.

KÖ22- Yukarılara doğru sıcaklık azaldığından açık hava basıncı artar.

YK

FÖ16-Yukarılara çıkıldıkça artan gaz miktarı, yoğunluğu dolayısıyla uygulanan basınçta artar.

FÖ19- Çünkü yukarılara doğru çıkıldıkça sıcaklık düşer. Sıcaklığın düşmesi basıncı arttırır.

FÖ22- Çünkü hava soğur ve basınç azalır.

L15- Yukarılara çıkıldıkça hava soğuk olur ve basınç azalır.

FBÖ27- yükseklere çıkıldıkça sıcaklık azalacağından basınç artar.

FBÖ39- hava değişimi sebebiyle basınç değiş̧imi olur (sıcaklık düşer bu yüzden açık hava basıncı düşer)

KÖ3- yükseklere çıkıldıkça KN düşer buna göre kaynamanın olabilmesi için buhar basıncının açık hava basıncına eşitlenmesi gerekir. Dolayısıyla KN düştüğü için açık hava basıncı da düşer.

A KÖ5-Deniz seviyesinden yukarılara çıkıldıkça açık hava basıncı azalır, bu şekilde KN düşer.

L39- Atmosfere yaklaşır.

Katılımcıların "Sıcaklık arttıkça açık hava basıncı nasıl değişir? Cevabınızın neden(ler)ini açıklayınız" sorusuna verdikleri yanıtlar Tablo 5'de belirtilmiştir. 
Tablo 5. Katılımcıların Sıcaklığın Açık Hava Basıncına Etkisine Illişkin Verdikleri Cevapların Eğitim Seviyelerine ve Alanlarına Göre Frekansları

\begin{tabular}{|c|c|c|c|c|c|c|c|c|c|c|c|}
\hline & (\%) & $f$ & $\begin{array}{l}\text { DS-KA } \\
f(\%)\end{array}$ & $\begin{array}{l}\text { DS- } \\
\text { YKA } \\
f(\%)\end{array}$ & DS-YK & DS-A & YS-KA & $\begin{array}{l}\text { YS- } \\
\text { YKA } \\
f(\%)\end{array}$ & YS-YK & YS-A & $f(\%)$ \\
\hline $\mathrm{L}$ & $1(1.4)$ & & $7(10.0)$ & $1(1.4)$ & $1(1.4)$ & $7(10.0)$ & - & - & $12(17.1)$ & $38(54.3)$ & $3(4.3)$ \\
\hline FBÖ & $3(3.9)$ & & $10(13.0)$ & $2(2.6)$ & $1(1.3)$ & $4(5.2)$ & - & $3(3.9)$ & $21(27.3)$ & $32(41.6)$ & $1(1.3)$ \\
\hline KÖ & $1(4.3)$ & & $2(8.7)$ & - & - & $1(4.3)$ & - & - & $14(60.9)$ & $5(21.7)$ & - \\
\hline FÖ & - & & $2(6.7)$ & - & $1(3.3)$ & $10(33.3)$ & $1(3.3)$ & - & $5(16.7)$ & $11(36.7)$ & - \\
\hline Toplam & $5(2.5)$ & & $21(10.5)$ & $3(1.5)$ & $3(1.5)$ & $22(11.0)$ & $1(0.5)$ & $3(1.5)$ & $52(26.0)$ & $86(43.0)$ & $4(2.0)$ \\
\hline
\end{tabular}

Açık hava basıncı ve sıcaklık arasındaki ilişkiye ilişkin katılımcıların büyük bir çoğunluğunun yanlış seçeneği işaretlemiş oldukları görülmekle birlikte, bu yanıtların en çok YS-A kategorisinde bulunduğu tespit edilmiştir. Doğru seçeneği işaretleyen katılımcıların ise yanıtlarının en çok DS-A kategorisinde bulunduğu belirlenmiştir. Eğitim seviyeleri ve alanları açısından bakıldığında ise lise, fen bilgisi öğretmenliği, fizik öğretmenliği öğrencilerin yanıtlarının en çok YS-A, kimya öğretmenliğindeki öğrencilerin ise cevaplarının en çok YS-YK kategorilerinde toplandığı görülmüştür. Bu soruya ilişkin katılımcıların ifadeleri aşağıda örneklendirilmiştir.

L47-Sıcaklık arttıkça gazların arasındaki boşluk artar. Dolayısıyla tanecik azalır ve basınç azalır.

TA FBÖ3- çünkü ısınan hava genleşeceğinden yeryüzünden daha yukarılara çıkmak isteyecek bu sebeple yeryüzünde basınç oluşturan hava miktarı azalır. Böylece basınç azalır.

KÖ22- Sıcaklık arttıkça havadaki gazlar genleşir, hacimleri artar ve yaptıkları basınç azalır.

L16-soğuk hava sıcak havadan ağırdır

L34- Isınan hava yükselir

KA L46- Çünkü alçak basınçta yüksek sıcaklık oluşur. Coğrafya bilgisi

KÖ12- Sıcaklık arttıkça taneciklerin hareketi artacak ve yükselecek, yeryüzünden uzaklaşacak

KÖ16- Isınan hava yükselir, basınç azalır.

FBÖ42- Isınan hava yukarı doğru çıkar, dolayısıyla basınç artar.

FBÖ12- çünkü gazlar genleşse de miktarı aynı kalır.

YKA L13- Açık hava basıncı atmosfer gazlarının oluşturduğu basınçtır. Buna bağlı olarak sıcaklığın bu gazları genleştirmesi kapalı bir kapta olmadıklarından bir etki etmez.

L21- Aynı şekilde nem gibi sıcaklığın artması da havadaki gaz miktarını arttıracağından açık hava basıncını arttırır.

L36- havanın kinetik enerjisi artar. Bundan dolayı basınç artar.

L67- Sıcaklık arttıkça gazlar hızlanır böyle olunca gazların uyguladığı basınçta artar.

L20- Çünkü P.V = n.R.T formülünden

FBÖ41- çünkü hava ısıtıldıkça hava moleküllerinin kinetik enerjileri artar ve artınca daha fazla

YK basınç uygularlar.

FÖ9- Açık hava basıncı yüksekliğe bağlıdır. Sadece yükseklik etki eder.

FÖ12- Sıcaklık artarsa havadaki gazların sahip olduğu kinetik enerji artar. Bu durum açık hava basıncının da artmasına neden olur.

KÖ10- Taneciklerin kinetik enerjisi artar, birbirlerine çarpmaları artar, basınç da artar.

KÖ15- Sıcaklıkla beraber basınç artar ve maddeye uygulanan basınç kuvveti artar. Sıcak havalardaki bunalmanın buna örnek olacağını düşünüyorum.

Beşinci soru olan "Bir uçak 1500m yüksekte uçmakta iken teknik bir arıza nedeniyle kapılarından bir tanesinin açıldığını düşünürsek aşağıdakilerden hangisi gerçekleşir? Cevabınızın neden(ler)ini açıklayını" sorusuna katılımcıların verdikleri yanıtlar Tablo 6'de belirtilmiştir. 
Tablo 6. Katılımcıların Beşinci Soruya iliş̧kin Verdikleri Cevapların Eğitim Seviyelerine ve Alanlarına

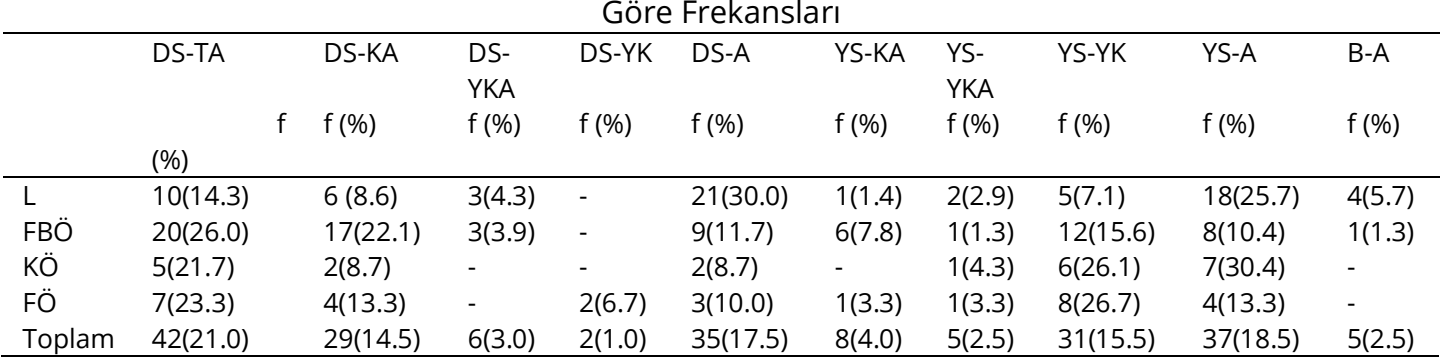

Bu soruda da üçüncü soruya benzer şekilde yükseklik ve açık hava basıncı arasındaki ilişki sorgulanırken, öğrencilerin bir olayı açıklamada bu konuya ne derecede hakim oldukları araştırılmıştır. Buna göre katılımcıların birçoğunun doğru seçeneği işaretledikleri görülmüş olmakla birlikte, DS-TA kategorisinde yanıtların yoğunlaştığı görülmektedir. Buna karşın yanlış seçeneği işaretleyenlerin içerisinde de yanıtların YS-A ve YS-YK kategorisindeki yoğunlaşması dikkat çekmektedir. Katılımcıların verdikleri yanıtların nedenlerine ilişkin örnekler aşağıda sunulmuştur.

L13- Uçağın bulunduğu yükseltide açık hava basıncı azdır. Insanlar bu ortamda nefes alamazlar bu durumda uçağın içindeki açık hava basıncı yapay olarak arttırılır. Bu tür bir arızada içerideki bu basınç dışarı çıkmak isteyecektir ve uçağın içinde ne varsa dışarı emilecektir.

L57- İ̧erideki basınç yüksek. Uçak yükseldikçe basınç azalacak. Kapı açılınca da az yoğun basınç olan yere doğru hava akışı olur.

FBÖ2- Çünkü o yükseklikte uçağın içindeki hava basıncı dışarıdan daha fazladır. Ayrıca hızın TA olduğu yerde basınç az olduğundan dolayı hava akışı basının fazla olduğu yerden yani uçağın içinden dışarıya doğrudur.

FÖ9- Uçağın bulunduğu yükseklikte dışarıdaki basınç daha az olduğu için çok yoğun ortamdan az yoğun ortama geçiş söz konusudur.

FÖ12- Deniz seviyesinden yükseklere çıkıldıkça açık hava basıncı azalır. Kapı açıldığı zaman bu yüzden dışarıya doğru şiddetli bir hava akışı olur.

L3- Yükseklik arttıkça basınç azalır ve uçakta basınç yüksek çünkü karadan kalkar ve uçak kalktı̆̆ında da kapalıdır. Uçak kapılarını açınca uçaktaki basınç azalır. Bu durum ortaya çıkar.

L6- açık hava basıncı uçağın içinde ve dışında eşit olmadığından dolayı uçağın içinden dışarıya doğru şiddetli bir hava akışı olur.

$K A$

FBÖ41- Çünkü oluşan basınç farkı çok yüksek olacağı için maddeler yüksek basınçtan düşük basınca doğru hareket edecektir.

KÖ12- Basınç dengesi bozulduğu için. Yoğun hava dışarıdaki az yoğun havaya gider.

KÖ14-iç basınç dış basınçtan büyük olduğu için.

FÖ6- Uçağın içindeki basınç yeryüzündeki kadar yüksektir.

L46-Deniz seviyesinden yükseklere çıkıldıkça basınç azalır, uçağın hızından dolayı uçağa uygulanan basınç azalır.

L67- Uçak hızlı gittiği için Po içerdekinden düşük olacaktır. Böylece içerideki hava dışarı akacaktır. FBÖ26- çünkü yüksek bölümlerde hava yoktur ve dış basınç çok düşüktür. Uçağın içindeki hava

YKA difüzyona uğrar basınç dengeye gelir.

KÖ5- Yukarıda basınç çok daha az olduğu için uçağın dışından içeriye doğru bir hava akısı olur. FÖ3- Uçak içindeki ve dış ortamdaki basınçlar farklıdır. Eşitleninceye kadar hava akışı iki yönde gerçekleşir.

L34- Uçağın içinde basınç az olduğu için içeri hava akışı olur.

YK L40-Çünkü yukarı doğru gidildikçe dış basınç artar.

F9- Dışarıdaki basınç içeriye göre daha fazladır. Bu yüzden dıştan içeri hava akışı olur. Kapıya 
doğru giden birisini içeri iter hava.

KÖ4- Basınçların aynı olduğunu düşünürsek hava akışı iki yönlü olur.

KÖ17- 1500m yükseklikte hava basıncı arttığından dolayı uçağa dışarıdan içeriye doğru hava akışı olur.

FÖ5- dışarıdaki hava basıncı içeridekine göre daha yüksek olduğu için.

FÖ7- Yüksekte iken hava yer değiştirir. Hava akışının meydana gelmesi ile iki yönlü akış olur. Katılımcıların "Çok yüksek bir dağa tırmanmakta olan bir dağcı zirveye yaklaştıkça aşağıdakilerden hangisi olabilir? Cevabınızın neden(ler)ini açıklayınız" sorusuna verdikleri yanıtlar Tablo 7'de belirtilmiştir.

Tablo 7. Katılımcıların Yüksekliğin Açık Hava Basıncına Etkisine Illişkin Verdikleri Cevapların Eğitim Seviyelerine ve Alanlarına Göre Frekansları

\begin{tabular}{|c|c|c|c|c|c|c|c|c|c|c|}
\hline & DS-TA & $\begin{array}{l}\text { DS-KA } \\
f(\%)\end{array}$ & $\begin{array}{l}\text { DS- } \\
\text { YKA } \\
\text { f (\%) }\end{array}$ & DS-YK & DS-A & YS-KA & YS-YKA & YS-YK & YS-A & $f(\%)$ \\
\hline L & $17(24.3)$ & $10(14.3)$ & $1(1.4)$ & $4(5.7)$ & $31(44.3)$ & $1(1.4)$ & & & $2(2.9)$ & $4(5.7)$ \\
\hline FBÖ & $18(23.4)$ & $27(35.1)$ & 3(3.9) & $15(19.5)$ & 7(9.1) & - & $1(1.3)$ & $1(1.3)$ & $4(5.2)$ & $1(1.3)$ \\
\hline KÖ & $6(26.1)$ & $2(8.7)$ & - & $3(13.0)$ & $2(8.7)$ & $2(8.7)$ & $3(13.0)$ & $3(13.0)$ & $2(8.7)$ & - \\
\hline FÖ & $6(20.0)$ & $8(26.7)$ & - & $7(23.3)$ & 7(23.3) & - & $1(3.3)$ & 1(3.3) & - & - \\
\hline Toplam & $47(23.5)$ & $47(23.5)$ & $4(2.0)$ & $29(14.5)$ & $47(23.5)$ & $3(1.5)$ & $5(2.5)$ & $5(2.5)$ & $8(4.0)$ & $5(2.5)$ \\
\hline
\end{tabular}

Açık hava basıncı ile yükseklik arasındaki ilişkinin bir başka olay çerçevesinde sorgulandı̆̆ı bu soruda da üçüncü ve beşinci soruya benzer şekilde katılımcıların çoğunlukla doğru seçeneği işaretledikleri görülmektedir. Katılımcıların yanıtlarının çoğunlukla DS-KA DS-TA ve DS-A kategorilerinde toplandığı belirlenmiştir. Eğitim seviye ve alanlarına göre bakıldığında ise lise öğrencilerinin yanıtlarının en çok DS-A; fen bilgisi öğretmenliği ve fizik öğretmenliği son sınıf öğrencilerinin yanıtlarının en çok DS-KA; kimya öğretmenliği öğrencilerinin yanıtlarının ise DS-TA kategorisinde bulunduğu görülmektedir. Katılımcıların ilgili sorunun nedenlerine ilişkin ifadeleri aşağıda örneklendirilmiştir.

L6- Yükseklere çıkıldıkça basınç azalır. Basınç azaldıkça atmosferde bulunan gazlar yetersiz olur. Böylece nefes almada zorlanır.

L17- Yukarı çıkıldıkça gaz yoğunluğu azalır. Bu yüzden nefes almak zorlaşır.

FBÖ3- Yükseklere çıkıldıkça hava miktarı azalır. Yani atmosfer basıncı azalır.

KÖ15- Dış basınç yukarı çıkıldıkça azalır. Ve kişi daha çok oksijen alabilmek için zorlanır.

KÖ21- zirveye doğru çıkıldıkça basınç azalır ve gaz moleküllerinin sayısı azalır.

TA FÖ3- Havadaki oksijen miktarı azalır. Alyuvar sayısı yükseğe çıktıkça artar( $\mathrm{O}_{2}$ tutabilmek için) FÖ10- Bunun sebebi yükseklere çıkıldıkça açık hava basıncının azalıp, oksijen miktarının da azalmasıdır.

FÖ13- Yukarılara çıkıldıkça basınç azaldığı için nefes almakta zorlanılır. nefes alıp vermede akciğerdeki basınç ile dış basınçönemlidir.

\section{L14- Açık hava basıncı azalır}

FBÖ9- çünkü denizden yukarı çıkıldıkça basınç azalır, hacim artar.

KÖ4- yorulur ayrıca basınç azalır.

KA KÖ7- Çünkü insan vücudu 1atm basınç altında çalışmaya alıştığı için basıncın daha az olduğu yerlerde nefes alıp vermek zor olacaktır.

FÖ6- Birim hava miktarı azalır.

FBÖ28- çünkü yukarı çıktıkça basınç artar. Oksijen miktarı azalır. Alveoldeki alyuvar miktarı artar. 
L70- Dağcının iç vücut basıncı yüksek zirvede basınç düşüktür. Basınç farkından dolayı zor nefes alır.

FBÖ2- Çünkü kişinin vücudunun iç basıncı açık hava basıncından büyüktür. Bu yüzden dışarıya nefes verme kolay ve dışarıdan nefes alması zorlaşır.

L5- Hava basıncı arttığından nefes alınması zorlaşır.

FBÖ51-Yükseklere çıkıldıkça basınç artar

FBÖ45- Açık hava basıncı artar nefes almakta zorlanır.

KÖ17-Yükseklere çıkıldıkça basınç arttığından dolayı nefes almak zorlaşır.

YK KÖ18- O2 miktarı artığından çok zor nefes alır.

FÖ8-Dağın zirvesine doğru basınç artar, bu basınç canlının oksijeni fazla alamamasına neden olur.

FÖ16-Havada bulunan gaz miktarı artar. Bu, vücudun gereğinden fazla gaz alamsıyla vücuda fazla basınç uygulanmış olur. Bu durumdan dolayı dağcı nefes almada zorlanır.

Katılımcıların "Akşam vakti deniz kıyısında yürürken hafifçe esen rüzgârın yönü için ne söylersiniz. Cevabınızın neden(ler)ini açıklayınız" sorusuna verdikleri yanıtlar Tablo 8'de belirtilmiştir.

Tablo 8. Katılımcıların Sıcaklığın Açık Hava Basıncına Etkisine Iliş̧in Verdikleri Cevapların Eğitim Seviyelerine ve Alanlarına Göre Frekansları

\begin{tabular}{|c|c|c|c|c|c|c|c|c|c|c|c|}
\hline & (\%) & $f$ & $f(\%)$ & $\begin{array}{l}\text { DS- } \\
\text { YKA } \\
f(\%)\end{array}$ & DS-YK & $f(\%)$ & YS-KA & YS-YKA & $f(\%)$ & $f(\%)$ & $f(\%)$ \\
\hline $\mathrm{L}$ & $1(1.4)$ & & $2(2.9)$ & $1(1.4)$ & $1(1.4)$ & $6(8.6)$ & $3(4.3)$ & $3(4.3)$ & $4(5.7)$ & $40(57.1)$ & 9 (12.9) \\
\hline FBÖ & $2(2.6)$ & & $7(9.1)$ & - & - & $9(11.7)$ & - & $11(14.3)$ & $16(20.8)$ & $22(28.6)$ & $10(13.0)$ \\
\hline KÖ & $1(4.3)$ & & $1(4.3)$ & - & $2(8.7)$ & - & $1(4.3)$ & $6(26.1)$ & $6(26.1)$ & $6(26.1)$ & - \\
\hline FÖ & $1(3.3)$ & & - & - & 1 (3.3) & $3(10.0)$ & - & $2(6.7)$ & $7(23.3)$ & $14(46.7)$ & $2(6.7)$ \\
\hline Toplam & $5(2.5)$ & & $10(5.0)$ & $1(0.5)$ & $4(2.0)$ & 18(9.0) & $4(2.0)$ & $22(11.0)$ & $33(16.5)$ & $82(41.0)$ & $21(10.5)$ \\
\hline
\end{tabular}

Tablo 8 incelendiğinde katılımcıların sıcaklık ve açık hava basıncı arasındaki ilişki sıcaklık ve açık hava basıncı arasındaki ilişkiyi ele alan dördüncü soruda olduğu gibi çoğunlukla yanlış seçeneği işaretlediği görülmektedir. Bununla birlikte katıımcıların yanıtlarının sırasıyla en çok YS-A, YS-YK ve YS-YKA kategorilerinde toplandığı belirlenmiştir. Doğru seçeneği işaretleyen katılımcıların ise yanıtlarının çoğunlukla DS-A ve DS-KA kategorilerinde toplandığı tespit edilmiştir. Buna göre katılımcıların ifadelerine ilişkin örnekler aşağıda sunulmuştur.

L17- karalar çabuk soğur ve erken ısınır. Denizler geç soğur geç ısınır. Akşam karalar soğur deniz ise daha sıcaktır. Soğuk havada basınç çok olur. Bu yüzden karadan denize doğru FBÖ2- Çünkü denizler karalara göre daha geç soğur. Kara o esnada denizden daha soğuk durumdadır. Bu da buraların üzerinde bulunan hava arasında basınç farkı yaratır. Bu yüzden rüzgar karadan denize doğrudur.

FBÖ55- çünkü akşam vakti deniz karadan daha sıcaktır. Sıcak yerin basıncı düşük olduğu için

TA yüksek basınçlı ortamdan, düşük basınçlı bir ortama bir hava akımı olur.

KÖ20- Denizler daha geç ısınıp daha geç soğuduğu için (özısısı yüksek) deniz üzerinde basınç daha az olur. Kara daha çabuk soğur. Dolayısıyla oluşan basınç farkından dolayı karadan denize doğru eser.

FÖ14- Denizdeki sıcaklık değişimi karadakine göre daha yavaştır. Akşam vakti hava soğuduğunda karadaki hava daha fazla soğuduğu için yoğunluğu artar ve yoğunluğun az olduğu denize doğru akar.

L23- Deniz sıcak, kara soğuk

KA

L42- Çünkü denizler karalara göre sıcak olduğu için

FBÖ73- Hava soğuduğu için karada basınç artar. Denize doğru bir akım oluşur.

FBÖ77- Karadaki basınç daha yüksektir. 
KÖ2- Rüzgar soğuk havadan sıcağa doğru eser. Gece soğuk olan yeryüzü olduğu için karadan denize doğru eser.

KÖ17- Karada hava basıncı daha yüksek olduğundan ötürü

L31- Deniz daha yavaş soğur. Hava soğuktan sıcağa hareket ettiği için karadan denize doğrudur.

FBÖ3- Karalar denizden çabuk soğuduğundan akşam vakti denizde yüksek basınç var iken, karada alçak basınç oluşur. Bu yüzden hava kütlesi alçak basıncın olduğu yere akar

FBÖ12- Deniz karaya göre daha geç soğur. Onun için kara soğuk olduğundan rüzgar da sıcaktan soğuğa doğru estiğinden, denizden karaya doğru eser.

YKA KÖ4- Kara çabuk ısınır çabuk soğur. Deniz geç ısınır geç soğur. Akşam deniz daha sıcak olduğu için hafif sıcak esinti denizden karaya doğru olur.

KÖ14- Çünkü basınç farkından dolayı. Basıncı büyük olan yerden küçük olan yere doğru olacağı için denizden karaya doğru eser.

FÖ3-Alçak hava basıncı ile yüksek hava basıncı yer değiştirir bu sebeple denizden karaya doğrudur

L6- Akşam güneşin batışıla denizde olan buharlaşma son bulur ve böylece buharlaşan hava denizden kıylya vurur.

L16-Deniz çabuk soğur kara hala sıcaktır. Ondan düşük basınçlı yere doğru hava akışı olur L67- Karalar denizlere göre daha zor ısınıp daha zor soğur. Sıcak olan yerde Po daha büyüktür. Gazlarda büyük basınç noktasından alçak basınç noktasına doğru hareket eder.

FBÖ32- Deniz karaya göre daha çabuk ısınır, daha çabuk soğur. Deniz akşam karadan daha soğuktur ve denizden karaya rüzgar eser.

YK FBÖ62- Denizler yüksek basınç bölgesi kara ise alçak basınç bölgesidir. O yüzden denizden karaya doğru akar.

KÖ5-Dalganın hareketinden dolayı

KÖ11- denizdeki nem oranı fazla olduğu için basınçlar denizden kıyıya esen rüzgarla eşitlenir.

FÖ19- Akşam vakti hava serinler ve açık hava basıncı artar. Basıncı artan hava aşağı iner ve denizden gelen rüzgâr bunu dengelemeye çalışır.

FÖ25- denizler daha çabuk soğuduğu için ısınan hava hareket eder yani denizden karaya doğru hava akışı olacaktır.

Katılımcıların verilen çeşitli ortamlardan hangisinde nefes almanın daha kolay olduğuna ilişkin bilgilerinin araştıııldığı soruya verdikleri yanıtlar Tablo 9'da belirtilmiştir.

Tablo 9. Katılımcıların Çeşitli Ortamların Açık Hava Basıncına Etkisine Illişkin Verdikleri Cevapların Ĕgitim Seviyelerine ve Alanlarına Göre Frekansları

\begin{tabular}{|c|c|c|c|c|c|c|c|c|c|c|c|}
\hline & (\%) & $f$ & $\begin{array}{l}\text { DS-KA } \\
f(\%)\end{array}$ & $\begin{array}{l}\text { DS- } \\
\text { YKA } \\
f(\%)\end{array}$ & DS-YK & DS-A & YS-KA & $\begin{array}{l}\text { YS- } \\
\text { YKA } \\
f(\%)\end{array}$ & YS-YK & $f(\%)$ & $f(\%)$ \\
\hline L & - & & $2(2.9)$ & - & $3(4.3)$ & 19(27.1) & - & $1(1.4)$ & 7 (10.0) & $30(42.9)$ & $8(11.4)$ \\
\hline FBÖ & - & & $7(7.1)$ & $1(1.3)$ & $7(9.1)$ & $33(42.9)$ & - & - & $11(14.3)$ & $18(23.4)$ & - \\
\hline KÖ & - & & $3(13.0)$ & $1(4.3)$ & $6(26.1)$ & $3(13.0)$ & $1(4.3)$ & - & $3(13.0)$ & $5(21.7)$ & $1(4.3)$ \\
\hline FÖ & $1(3.3)$ & & - & - & $1(3.3)$ & $6(20.0)$ & $2(6.7)$ & $2(6.7)$ & 5 (16.7) & $10(33.3)$ & $3(10.0)$ \\
\hline Toplam & - & & $2(2.9)$ & - & $3(4.3)$ & 19(27.1) & - & $1(1.4)$ & $7(10.0)$ & $30(42.9)$ & $8(11.4)$ \\
\hline
\end{tabular}

Sıcaklık ve nemin açık hava basıncına etkisinin araştıııldığı bu soruda katılımcıların yanıtlarının çoğunlukla YS-A ve DS-A kategorilerinde toplandığı görülmektedir. Sıcaklığın ve nemin araştıııldığı diğer sorulara benzer şekilde bu soruda da yanlış yanıtların yoğunlaşması ve doğru seçeneği işaretlenmesine rağmen bunun nedenlerini açıklayamamaları birbiri ile tutarlıdır. Eğitim seviye ve alanlarına göre bakıldığında lise ve fizik öğretmenliği öğrencilerinin yanıtlarının en çok YS-A; fen bilgisi öğretmenliği öğrencilerinin yanıtlarının DS-A ve kimya öğretmenliği öğrencilerinin ise 
yanıtlarının DS-YK kategorisinde toplandığı görülmektedir. Katılımcıların verdikleri yanıtlara ilişkin örnekler kategoriler bazında aşağıda sunulmuştur.

$T A$

FÖ21- Kuru havada açık hava basıncı fazladır daha fazla O2 bulunacă̆ından dolayı. Serin yani soğuk havada da basınç fazladır. Basıncın normal olduğu yerlerde daha iyi nefes alırız.

L41- oksijen daha fazla olduğu için

KÖ3- Açık hava basıncı serin ortamlarda daha çok hissedilir, nemli hava olduğunda daha zor

KA nefes alıriz.

FÖ1- oksijen daha fazla bulunur.

L13- çünkü serin ve nemli havada oksijen atmosferden aşağlya iner böylelikle rahat bir şekilde nefes alınabilir.

FBÖ58- sıcak ve nemli havada basınçtan dolayı nefes almak zorlaşır. çünkü basınç artıyor

KÖ15- diğer soruda sıcaklık arttıkça basınç artar demiştim. Bununda nedeni aynıdır. Kuru

YKA havada nemli havaya göre daha çok oksijen vardır.

FÖ26-sıcaklık arttıkça basınç da artacağından nefes almakta zorlanılır. Ama serin havada daha kolay nefes alınır.

FÖ25- sıcak ve kuru bir havada açık hava basıncı daha fazladır.

L6- Nem artışı olduğu zaman basınçta artar

FBÖ4- Nemli havada yoğun basınçtan dolayı nefes almak zordur. Aynı şekilde sıcak havadaki atmosfer basıncı yüksek olacağından nefes almak zordur.

KÖ6- Basınç az, tanecikler az hareketli bu yüzden serin ve kuru bir havada

KÖ9- Sıcak ortamda gaz miktarı fazla olduğundan yoğun bir ortam oluşmuş olur. Bu yüzden

YK serin ortamda daha kolay nefes alınır.

FÖ5- Basınç serin ve kuru ortamda daha düşük olduğu içindir.

FÖ7- Çünkü serin ve nemli havada oksijen çözünmüş halde bulunur.

FÖ14- oksijeni tutabilmek için akciğerin nemli olması gerekir. Nem kazanabilmek için havadaki nem de kullanılır. Dolayısıyla $D$ şıkkı en idealdir.

FBÖ74- serin ve kuru bir havada basınç daha düşüktür.

PÖ2- sıcak ve nem basıncı arttıracağı için serin ve kuru bir havada

Katılımcıların, şişirilip ağzı bağlanmış bir elastik balonun verilen çeşitli durumların hangisinde hacminin artacağına ilişkin soruya verdikleri yanıtlar Tablo 10'da belirtilmiştir.

Tablo 10. Katııımcıların Yükseklik ve Sıcaklığın Açık Hava Basıncına Etkisine Iliş̧kin Verdikleri Cevapların Eğitim Seviyelerine ve Alanlarına Göre Frekansları

\begin{tabular}{|c|c|c|c|c|c|c|c|c|c|c|c|}
\hline & (\%) & f & $f(\%)$ & $\begin{array}{l}\text { DS- } \\
\text { YKA } \\
\text { f (\%) }\end{array}$ & $\begin{array}{l}\text { DS- } \\
\text { YK } \\
f \\
(\%)\end{array}$ & DS-A & YS-KA & YS-YKA & YS-YK & $f(\%)$ & $f(\%)$ \\
\hline L ... & $3(4.3)$ & & $3(4.3)$ & - & - & $1(1.4)$ & 13(18.6) & $1(1.4)$ & $3(4.3)$ & $18(25.7)$ & $28(40.0)$ \\
\hline FBÖ & $7(9.1)$ & & $7(9.1)$ & - & - & $6(7.8)$ & $30(39.0)$ & $6(7.8)$ & $3(3.9)$ & $11(14.3)$ & $7(9.1)$ \\
\hline КÖ & $2(8.7)$ & & $2(8.7)$ & $1(4.3)$ & - & - & $12(52.2)$ & $1(4.3)$ & $1(4.3)$ & $3(13.0)$ & $1(4.3)$ \\
\hline FÖ & $2(6.7)$ & & $1(3.3)$ & - & - & $1(3.3)$ & $8(26.7)$ & $1(3.3)$ & $2(6.7)$ & $8(26.7)$ & 7 (23.3) \\
\hline Toplam & $14(7.0)$ & & $13(6.5)$ & $1(0.5)$ & - & $8(4.0)$ & $63(31.5)$ & $9(4.5)$ & $9(4.5)$ & $40(20.0)$ & $43(21.5)$ \\
\hline
\end{tabular}

Tablo 10'a göre katıımcıların çoğunun bu soruyu boş bıraktığı ya da yanlış seçeneği işaretlediği görülmektedir. Katııımcıların yanıtlarının çoğunlukla YS-KA, B-A ve YS-A kategorilerinde toplandığı görülmektedir. Eğitim seviye ve alanlarına göre incelendiğinde lise son sınıf öğrencilerinin yanıtlarının çoğunlukla B-A, fen bilgisi öğretmenliği ve kimya öğretmenliği son sınıf öğrencilerinin YS-KA ve fizik öğretmenliği öğrencilerinin YS-KA/B-A kategorilerinde toplandığı belirlenmiştir. Buna göre katılımcıların ifadelerine ilişkin örnekler aşağıda belirtilmiştir.

$T A$

L67- Soğuk ortamda büzüşür. Yükseklere çıkıldıkça dış basınç azalır. Iç basınç dış basınçtan büyük olacağı için şişer. Havasız ortamda iç basınç daha büyük olacağı için şişer. 
FBÖ37- Yalnızca II ve III de dış ortam düşük basınçtadır. Balon iç basınçla dış basıncı eşitlemek için hacmini genişletir.

FBÖ25- Yükseklik arttıkça basınç azaldığı için hacim artar. Havası boşaltılmış bir ortamda balona baskı yaparak hava basıncı olmadı̆̆ı için balonun hacmi artar. Soğukta ise balon büzüşür.

KÖ4-Yükseklere çıkıldıkça basınç azalır. Sıcaklık, n sabit olduğuna göre hacim artar II'de. III de basınç azaldığı için hacim artar.

FÖ25- II-elastik balonun hacmi değiş̧kendir. Sıcaklıkları aynı iken yükseltisi fazla olan yerde basınç azalır ve şişer. III. Havası boşaltıımışsa, dış basınç içe göre daha az olacağından balon şişecektir.

L33- yukarıda basınç azalır. Balon elastik olduğu için basınç azalırsa hacim artar.

L42- P.V=n.R.T Çünkü yüksekte basınç azalır. Hacimle basınç ters orantılı olduğu için hacim artar.

L44- Elastik balonda basınç açık hava basıncına eşittir. I'de basınç sabit sıcaklık azalırsa hacim azalır. II'de sıcaklık sabit ama yükselti arttığından basınç azalır. Hacim artar.

FBÖ54-II'de basınç daha az olduğu için balon genleşir ve hacmi artar.

FBÖ63-yükselti fazla ise atmosfer basıncı azalır. Balonun dışındaki basınç azaldığından balon şişer.

KA KÖ3- II. maddede balonun hacmi artar çünkü balona etki eden dış basınç yükseklere çıkıldıkça azalır.

KÖ10-II. yükselti fazla olduğunda açık hava basıncı azalır. Balonun içindeki basınç fazla olduğu için hacmini arttırarak basıncını azaltma yönüne gider.

FÖ27- II. yükseltisi fazla olan yerlerde hacmi artar. Çünkü şişer.

FÖ8- çünkü aynı havası boşaltılmış balonda basınç azdır. Basıncın az olduğu yerde hacim fazladır.

L21- Bu üç durumda da havadaki gaz miktarı ve açık hava basıncı azalır. Açık hava basıncı hacimle ters orantılı olduğundan hacim artar.

FBÖ11- Sıcaklık azaldıkça büzülme gerçekleşir. Bu nedenle I'de hacmin artması beklenmez. Yükseklere çıkıldıkça basınç artar ve buna bağlı olarak basınç ters orantılı olan hacim azalır. III de ise havası boşaltıldığı için ortam basıncı azalır ve hacim artar

FBÖ28- Çünkü soğuk ortamda hacmi küçülür. Yükseğe çıktıkça hava basıncı artar hacim yine

YKA küçülür. Havası boşaltılmış ortamda hacim artar

KÖ22-I, II, III dış basınçlar az olduğu için hepsinde balonun hacmi artar.

KÖ5- I-balonu pistonlu kap gibi düşünebiliriz. Aynı basınçta daha soğuk bir yere koyduğumuzda sıcaklık azaldı̆̆ı için basınç azalır, hacim artar (P ile V ters orantılı). II. aynı sıcaklıkta yükseltisi fazla bir yerde, yükseklere çıkıldıkça açık hava basıncı düşer. Basınç düşerse hacim artar. III. basınç azalır, hacim artar.

L34- P.V=n.R.T formülünden II'de hacim azalır. III de değişmez (hiçbir etki yok dışarıdan)

FBÖ29- II'de basınç daha fazla olduğundan balon şişer.

YK FBÖ27- Yükselti fazlaysa basınç fazladır. Bu da balonu şişirir.

FÖ22- Soğuk havada daha az açık hava basıncı vardır bu yüzden I.

FÖ26- I.Sıcak hava balonun hacmini azaltır. Ama soğuk havada hacmi artar.

Genel olarak değerlendirildiğinde katılımcıların açık hava basıncını etkileyen etmenlerden olan sıcaklık ve nem ile ilgili sorularda yükseklik ile ilgili olan sorulara oranla daha fazla yanlış yanıt verdikleri görülmektedir. Açık hava basıncını etkileyen değişkenleri ele alan olaylar şeklinde sorulan sorularda da benzer şekilde yanlış yanıtların fazlalaştığı görülmektedir. 


\section{SONUÇ, TARTIŞMA ve ÖNERILER}

Bir konuyu anlayabilmek için öncelikle o konuyla ilgili temel bilgilerin çok iyi kavranması ve birbirleri ile ilişkilendirilerek doğru bir biçimde yapılandırıması gerekir. Özellikle soyut kavramların yoğun olduğu fen konularında öğrencilerin bu kavramları yapılandırmaları daha da önemli hale gelmektedir. Açık hava basıncı bu konulardan birisidir ve doğası itibari ile sonuçları hissedilebilir olsa bile havayı oluşturan gaz tanecikleri doğrudan gözlemlenemediğinden anlaşılması güçleşmektedir. Bunun yanında açık hava basıncının anlaşılabilmesi için öğrencilerin çok sayıda kavramı iyi bilmesi ve bunları ilişkilendirebilmesi gerekir. Bu ilişkiler iyi kurulmadığı takdirde öğrenciler konuyu teorik olarak kavramada, ilişkili günlük hayat problemlerini anlamada ve bu olayları bilimsel olarak açıklamada zorluk yaşayacaklardır. Atmosfer basıncının anlaşılması zor bir konu olarak görülmesinin nedenlerinden biri de basınç, kuvvet, yoğunluk ve atmosfer basıncı kavramlarının birbirine karıştııılmasıdır (Besson, 2004; Fassoulopoulos, Kariotoglou ve Koumaras, 2003; Papadimitriou ve Londridou, 2001; Tytler, 1998). Bu çalışmada son sınıf lise öğrencelerinin, fen bilgisi öğretmen adaylarının, fizik öğretmen adaylarının ve kimya öğretmen adaylarının açık hava basıncını, açık hava basıncını etkileyen faktörleri ve bu konuya ilişkin oluşturulan çeşitli problem durumlarına getirdikleri açıklamaları incelenmiştir.

Elde edilen sonuçlar lise öğrencilerinin ve öğretmen adaylarının açık hava basıncını doğru ve tam olarak açıklamada oldukça yetersiz olduğunu göstermektedir. Bunun yanında katılımcıların yaklaşık yarısının eksik ve eksikle birlikte yanlış bilgiye sahip olduğu görülmektedir. Benzer şekilde Doymuş, Canpolat, Bayrakçeken ve Gürses (1998) kimya bölümü öğrencilerinin, Birinci-Konur ve Ayas (2010) sınıf öğretmeni adaylarının ve Demircioğlu, Tütüncü ve Demircioğlu (2016) ise lise 10. sınıf öğrencilerinin gaz kavramını açıklamada güçlük çektiğini ve çeşitli yanılgılara sahip olduklarını belirtmişlerdir. Katılımcıların açık hava basıncını, Toriçelli deneyi üzerinden ve sayısal problemlerde sıkıkla karşılaştıkları " $76 \mathrm{cmHg}$ " değeri, deniz seviyesi ve $0^{\circ} \mathrm{C}$ gibi ortam koşullarını belirterek tanımlamaya çalışıkları tespit edilmiştir. Bu sonuç katılımcıların ilgili kavramın ne olduğundan ziyade deniz seviyesi ve $0^{\circ} \mathrm{C}$ deki değerinin ne olduğuna odaklandıklarını göstermektedir. $\mathrm{Bu}$ sonucun ortaya çıkması; kitaplarda açık hava basıncının detaylı tanımına çok az yer verilmesine karşın deniz seviyesi ve $0^{\circ} \mathrm{C}$ de açık hava basıncı ile ilgili benzer tarzdaki sayısal işlem gerektiren problemlere çok sıklıkla yer verilmesi ile açıklanabilir (de Berg, 1989; Wiebe, ve Stinner, 2010; Nakiboğlu ve Yıldırır, 2011; Gillette ve Sanger, 2014; Gegios, Salta ve Koinis, 2017). Nitekim katılımcıların açıklamalarından alınan "KÖ19: açık hava basıncı 76cmHg'dir, L18: açık hava basıncı $0^{\circ} \mathrm{C}$ de, deniz seviyesinde yapılan basınca denir" şeklindeki ifadeler bunu desteklemektedir. Bu soruya verilen cevaplar eğitim seviyesine göre incelendiğinde öğretmen adaylarının lise öğrencilerinden daha iyi yanıt vermelerine karşın bu yanıtların beklenen oranda iyi olmadığı görülmektedir. Genel olarak bakıldığında ise tüm eğitim seviyelerinde ve özellikle öğretmen adaylarının verdikleri cevapların YKA ve YK kategorisinde yoğunlaşmakta olup katılımcıların büyük bir çoğunluğu açık hava basıncını doğru olarak tanımlayamamaktadırlar. Öğretmen adaylarının konuya ilişkin lisans öğrenimleri boyunca birçok ders almasına karşın açıklamalarının lise öğrencilerinden çok farklılaşmaması onların konuları yüzeysel ve ezbere öğrendiklerini göstermektedir (Önder ve Beşoluk, 2010). Bunun yanında kitaplardaki açıklamaların eksikliği ve açık uçlu soruların yerine çoktan seçmeli soruların TEOG, LYS gibi sınavlara hazırlık nedeni ile eğitim öğretim faaliyetlerinde sıklıkla kullanılması, üniversiteye yerleşen öğrencilerin önceki ders çalışma alışkanlıklarını kolay değiştirememeleri ve üniversitelerde dahi çoktan seçmeli sınavların kısmen de olsa devam etmesi öğretmen adaylarının olay ve olguların nedenlerinin açıklanmasına yoğunlaşıp (Beşoluk ve Önder, 2010) bu doğrultuda ihtiyaç hissetmekten ziyade ezberleyip doğru sonuca götüren yüzeysel bilgiye odaklanmalarına sebep olmaktadır.

Açık hava basıncını etkileyen faktörlere ilişkin sorulardan nem ile ilgili olan sorunun en düşük oranda doğru olarak cevaplandırıldı̆̆ görülmektedir. Katılımcıların sadece \%13'ü ikinci soruda doğru seçeneği işaretlemiş ve tam anlama kategorisinde açıklama bulunmazken yalnız bir katılımcının kısmi anlama kategorisinde yanıt verdiği tespit edilmiştir. Nem oranındaki artışın açık hava basıncının artmasına neden olduğu çünkü nem oranı arttıkça havanın ağırlı̆ının arttığı 
şeklinde yanlış bir kanının yaygın olarak yerleşik olduğunu gösteren katılımcı ifadeleri mevcuttur; "FBÖ27- Nemli hava daha ağırdır bu yüzden daha fazla basınç uygular", "FBÖ2- Açık hava basıncı artar. Çünkü havada bulunan tanecik sayısı artacağından bu taneciklerin insanlar üzerinde uygulayacağı ağırlıktan dolayı basınç artacaktır". Benzeri bir sonucu Akbaş ve Uzunöz (2013) uyguladıkları deneysel işlem öncesinde 9. sınıf öğrencilerinin yaklaşık üçte birinin nemli havanın kuru havaya göre daha ağırdır yanılgısına sahip olduğunu belirtmişlerdir. Bunun yanı sıra Pidwirny (2016) bu yanılgının genel bir yanılgı olduğunu ifade etmiştir.

Sıcaklı̆ı̆ açık hava basıncına etkisi ile ilgili olan dört numaralı soruda \%27 oranında doğru seçenek işaretlenirken, tam anlama ve kısmi anlama kategorisindeki cevapların toplamının \%13 olduğu görülmektedir. Sıcaklıkla ilgili doğru cevaplama oranının nem ile ilişkili soruya göre biraz daha yüksek olduğu ancak yine de istenilen düzeyde olmadığı görülmektedir. Bununla birlikte yaygın bir yanlış olan sıcaklık arttıkça açık hava basıncının artacağı kanısının genel olarak katılımcılarda mevcut olduğu belirlenmiştir. Buna benzer bir sonuç Akbas ve Gencturk (2011) 9. sınıf öğrencileri ile yaptıkları çalışmasında çalışma grubunun yaklaşık üçte birinde bulunmuştur. Bunun yanında ifadeler incelendiğinde bazı katılımcıların açık hava basıncına sıcaklığın etkisini, kapalı kaplardaki gazların basıncı gibi açıklamaya çalıştıkları ve hata yaptıkları görülmektedir; “KÖ2- Nem yani su buharı molekülleri artar ve molekül sayısı artınca diğer değişkenler sabit olursa tabi ki basınç artar $(P . V=n . R . T)$ ", "KÖ10- Taneciklerin kinetik enerjisi artar, birbirlerine çarpmaları artar, basınç da artar". Yükselti ile açık hava basıncının nasıl değiştiğine ilişkin üç numaralı soruya verilen cevaplar incelendiğinde katılımcıların \%78.5'inin doğru seçeneği işaretlediği görülmektedir ancak katılımcıların sadece üçte biri ilgili soruya tam ve kısmi anlama kategorisinde cevaplar vermişlerdir. Ayrıca katılımcıların \%39.5'i doğru seçeneği işaretlemiş olmalarına rağmen anlamama kategorisinde yer almışlardır. Bu veriler katılımcıların büyük bir bölümünün yükselti ile açık hava basıncının ters orantılı olarak değiştiğini bildiklerini ancak bu ilişkinin nedenini açıklayamadıklarını yani ezber bilgilerle seçeneklerden birini tercih ettiklerini göstermektedir. Bunun yanında yükseltinin artması ile açık hava basıncının artacağına ilişkin yanılgı bazı katıımcıların ifadelerinde görülmektedir; “FBÖ11- Yukarılara çıktıkça atmosferde bulunan gaz miktarı artar. Buna bağlı olarak basınçta artar", "FÖ16-Yukarılara çıkıldıkça artan gaz miktarı, yoğunluğu dolayısıyla uygulanan basınçta artar". Aynı yanılgı çeşitli çalışmalarda da bulunmuştur (Aron, Francek, Nelson ve Bisart, 1994; Akbas ve Gencturk, 2011; Şahin ve Çepni, 2012; Yalçınkaya ve Boz, 2015; Pabuçcu, 2016). Katılımcıların günlük hayatla ilişkili problemlerden yükselti ile ilgili olan sorulara verdikleri cevaplar incelendiğinde, beşinci soruda \%57 sinin doğru seçeneği işaretlediği ancak katılımcıların \%39.5'inin TA ve KA kategorisinde açıklamalarda bulunduğu belirlenmiştir. Altıncı soruda ise katılımcıların \%87'sinin doğru seçeneği işaretlediği ancak katılımcıların \%48.5'inin TA ve KA kategorisinde yanıtlar verdiği görülmüştür. Bununla birlikte dikkat çekici bir sonuç olarak ilgili sorularda yanıtların azımsanmayacak oranda DS-A kategorisinde toplandığı görülmektedir. Katılımcıların ilgili sorulara sadece yükseklik ile ilgili bilgilerini yordayan üçüncü sorudan daha yüksek oranda tam anlama kategorisinde yanıt vermeleri, ilgili sorularda yer alan olayların filmlerde ve belgesellerde sıklıkla karşılaşılan olaylar olması ile açıklanabilir. Günlük hayatla ilişkili olarak hazırlanan problemlerden sıcaklık ile ilgili olan yedi numaralı soruya katılımcıların verdikleri yanıtlar incelendiğinde sadece \% 19 'unun doğru seçeneği işaretledikleri ve tam anlama ve kısmi anlama kategorisinde değerlendirilen yanıtların ise sadece \% 9.5 olduğu görülmektedir. Bu çalışmaya paralel olarak Mandrikas, Skordoulis ve Halkia (2013) çalışma grubundaki 60 öğretmen adaylarından sadece bir tanesinin rüzgârın farklı konumlardaki açık hava basıncındaki farktan oluştuğunu belirttiğini ifade etmiştir. Polito, Tanner ve Monteverdi (2008)'nin çalışmasında belirtildiği gibi rüzgarın okyanus dalgalarından oluştuğunu belirten yanlış ifadelere bu çalışmada da rastlanmaktadır (KÖ5: Dalganın hareketinden dolayı). Bununla birlikte sıcaklık ile ilgili salt bilgi içerikli soruya verilen yanıtlar incelendiğinde bu soru ile yanıtların tutarlı olduğu görülmektedir. Katılımcıların ifadeleri incelendiğinde karaların ve denizlerin gün içerisindeki ısınma ve soğumaları ile ilgili genel bir bilgileri olmasına rağmen bu durumların açık hava basıncı ile ilişkisini kurmada zorluk çektikleri görülmektedir. Ayrıca ilgili soruların doğru yanıtlama oranları incelendiğinde ise eğitim seviyeleri 
açısından ciddi olarak farklılaşmadığı görülmektedir. Pabuçcu (2016) ve Özmen, Ayas ve Coştu (2002) fen bilgisi öğretmen adayları ile yaptıkları çalışmalarda benzer şekilde öğretmen adaylarının fen ile ilgili bilgilerini günlük olaylarla ilişkilendirmede sorun yaşadıklarını belirtmiştir. Günlük hayattaki problem durumları ile bilimsel bilgiler arasında ilişki kurmada yaşanılan zorluğun nedeninin sınıflarda anlamlı öğrenmeler yerine ezber öğrenmelerin yapılması olduğu belirtilmektedir (Ayas, Çepni ve Akdeniz, 1993; Bayram, Sökmen ve Savcı, 1997; Yıldııım, Kurt ve Ayas, 2011).

Birden fazla değişkenle oluşturulan günlük hayatta karşılaşılan problem durumlarını ele alan sorularda katılımcıların genel olarak açıklamada çok güçlük çektikleri görülmektedir. Sıcaklık ve nemin birlikte açık hava basıncına etkisine açıklamada çok zorlandıkları görülmektedir. Buna göre sekizinci soruda tam anlama ve kısmi anlama kategorisinde verilen yanıtların $\% 8$ olduğu görülmektedir. Ayrıca bu soruda katılımcıların \%30.5 doğru seçeneği işaretlemelerine rağmen yaptıkları açıklamaların anlamama kategorisinde toplandığı görülmüştür. Ifadelerden anlaşıldığı üzere katılımcıların kendi günlük hayattaki deneyimlerinden yola çıkarak işaretleme yaptıkları karşımıza çıkmaktadır. Yükselti ve sıcaklığın açık hava basıncı ile ilişkisinin araştırılı̆̆ı son soruda ise katılımcıların \%18'inin doğru seçeneği işaretlediği ve katılımcıların sadece \%7'sinin soruyu tam olarak açıkladıkları görülmektedir. Bu soruya ilişkin katılımcıların ifadeleri incelendiğinde ise katılımcıların bu soruyu daha çok kapalı kaplardaki gaz basıncının açıklanmasına ilişkin prensipleri kullanarak yanıtlamaya çalıştıkları görülmektedir. Eğitim seviyeleri açısından karşılaştıııldığında ise birden fazla değişkenle oluşturulan günlük hayatta karşılaşılan problem durumlarını ele alan sorularda benzer şekilde ciddi farklılıklar olmadığı görülmektedir. Lin, Cheng ve Lawrenz (2000) yaptıkları çalışmada 11. sınıf lise öğrencilerinin ve onların kimya öğretmenlerinin gazlar konusunda benzer yanılgılara sahip olduğunu ifade etmektedir. Bunun yanında bu çalışmaya benzer şekilde iki değişkenin birlikte değişiminin gaz basıncındaki değişimi anlamayı zorlaştırdığını belirten çalışmalar bulunmaktadır (Basca ve Grotzer, 2001; Taylor ve Lucas 2000). Bu çalışmaya benzer şekilde Hacioglu, Durukan ve Cigdem (2016) çalışmasında katılımcıların birçoğu soruları açıklamada $P . V=n . R . T$ denklemini kullanmaları ise onların açık hava basıncını, kapalı kaptaki gaz basıncı gibi değerlendirdiklerini yani bu kavramları birbiri ile karıştırdıklarını ortaya koymaktadır. Bodner (1991) öğrencilerin yükseklik ile açık hava basıncının değişimini açıklamada P.V=n.R.T denklemini kullanmalarını onların ideal gaz denklemini anlamadan ezberlemeleri ile açıklamaktadır.

Sonuç olarak çalışmada katılımcıların açık hava basıncını, onu etkileyen unsurları ve ilişkili olayları açıklamakta çoğunlukla yetersiz kaldıkları ve açıklamalarında bilimsel bilgiler ile çelişen önemli düzeyde ve çok sayıda hatanın bulunduğu görülmüştür. Açıklamalardaki hata ve eksiklikler; kitaplardaki açık hava basıncı ile ilgili bilgilerin yetersizliği, açık hava basıncı ile kapalı kaplardaki basıncın özellikleri ve farklarına yeterince yer verilmemesi, derslerde öğretim ya da değerlendirme amacıyla kullanılan problemlerin yüzeysel ve matematiksel işlem odaklı oluşu, derslerin çok disiplinli bakış açısı ile işlenmemesi, kavramların yüzeysel, ezber tanımlar olarak verilmesi ve anlamlı öğrenmeyi sağlayacak kavramlar arası bağların kurulmaması ve eğitim sisteminde var olan birçok nedenden dolayı meydana gelmiş olabilir. Bir olayla ilgili değişken sayısı arttığında doğru açıklamaların oranının da düştüğü görülmektedir. Oysaki günlük fen olayları genellikle çok boyutlu, çok değişkenli ve disiplinler arası özelliğe sahiptir. Dolayısıyla tek boyutlu bir bakış açısıyla fen olaylarının iyi ve doğru açıklanması mümkün değildir. Eğer fen alanlarının öğretimi çok boyutluluğu ve disiplinler arası özelliği göz önünde bulundurulmadan yürütülür ve sadece kavramların tanımlanması ve matematiksel işlemlere odaklanılarak verilirse, öğrencilerin karşılaştıkları olayları açıklamada güçlük çekmeleri beklenen bir sonuç olur. Bunların yanı sıra çalışmanın önemli sonuçlarından biri de eğitim seviyesi artmış olmasına ve konuyu içeren birçok ders alınmış olmasına rağmen son sınıf öğretmen adayları ile lise öğrencileri arasında beklenilen düzeyde fark görülmemesidir. Bu durum katılımcılarla sınırlı olsa da geleceğe yönelik umut verici bir tablo sergilememektedir. Bu nedenle, benzer çalışmaların genişletilerek elde edilen sonuçların ders kitaplarının yazımında ve eğitim-öğretim faaliyetlerinin planlanmasında bilimsel veriler olarak göz önüne alınması tüm paydaşlara önerilmektedir. 


\section{Kaynakça}

Abraham, M. R., Grzybowski, E. B., Renner, J. W. ve Marek, E. A. (1992). Understandings and misunderstandings of eighth graders of five chemistry concepts found in textbooks. Journal of Research in Science Teaching, 29, 105-120.

Akbas, Y. ve Gencturk, E. (2011). The effect of conceptual change approach to eliminate 9th grade high school students' misconceptions about air pressure. Educational Sciences: Theory and Practice, 11(4), 2217-2222.

Akbaş, Y. ve Uzunöz, A. (2013). Ortaöğretim dokuzuncu sınıf öğrencilerinin nem kavramıyla ilgili yanılgılarını gidermede kavramsal değişim yaklaşımının etkililiği. Kastamonu Eğitim Dergisi, 21(2), 523-542.

Akşit, F. (2011). Atmosfer basıncı konusunun deney yöntemi ile öğretimi. e-Journal of New World Sciences Academy EducationSciences, 6(3), 2210-2228.

Aksoy, B. (2003). Deney yöntemi ile atmosfer basıncı konusunun öğretimi üzerine bir model. Gazi Üniversitesi Gazi Eğitim Fakültesi Dergisi, 23(3), 207-226.

Aron, R. H., Francek, M. A., Nelson, B. D. ve Bisart, W. J. (1994). Atmospheric misconceptions. Science Teacher, 61(1), 30-33.

Ayas, A., Çepni, S. ve Akdeniz, A.R. (1993). Development of the Turkish secondary science education. Science Education, 77(4), 440-443.

Ayas, A., Karataş, Ö. F. ve Coştu, B. (2003). Kavram öğretiminde çalışma yapraklarının kullanılması. Pamukkale Üniversitesi Eğitim Fakültesi Dergisi, 2(14), 33-48.

Barke, H. D. Hazari, A., ve Yitbarek, S. (2009). Misconceptions in chemistry: Addressing perceptions in chemical education, Berlin: Springer-Verlag, Germany.

Basca, B. B. ve Grotzer, T. A. (2001). Focusing on the nature of causality in a unit on pressure: How does it affect student understanding? Presented at the American Educational Research Association (AERA) Seattle.

Bayram, H. Sökmen, N., ve Savcl, H. (1997). Temel fen kavramlarının anlaşılma düzeyinin saptanması, Marmara Üniversitesi Atatürk Eğitim Fakültesi Eğitim Bilimleri Dergisi, 9, 89-100.

Beşoluk, Ş. ve Önder, í. (2010). Öğretmen adaylarının öğrenme yaklaşımları, öğrenme stilleri ve eleştirel düşünme eğilimlerinin incelenmesi. Illköğretim Online, 9(2), 679-693.

Besson, U. (2004). Students' conceptions of fluids. International Journal of Science Education, 26(14), 1683-1714.

Birinci-Konur, K. ve Ayas, A. (2010). Sınıf öğretmeni adaylarının gazlarda sıcaklık-hacim-basınç ilişkisini anlama seviyeleri, Türk Fen Eğitimi Dergisi,7(3), 128-142.

Bodner, G. M. (1991). I have found you an argument: The conceptual knowledge of beginning chemistry graduate students. J. Chem. Educ, 68(5), 385-388.

Brown, T. L., LeMay, H. E., Bursten, B. E. ve Brunauer, L. S. (1994). Chemistry: the central science , 8 (7 th edition). Englewood Cliffs, NJ: Prentice Hall.

Bueche, F. J. ve Jerde, D. A. (2003). Fizik ilkeleri-l (Çev. Ed.: K. Çolakoğlu), Düzeltilmiş ikinci Türkçe Baskı. Ankara: Palme Yayıncılık.

de Berg, K. C. (1989). The emergence of quantification in the pressure-volume relationship for gases: A textbook analysis. Science Education, 73(2), 115-134.

de Berg, K. C. (1995). Revisiting the pressure-volume law in history-what can it teach us about the emergence of mathematical relationships in science? Science ve Education, 4(1), 47-64.

De Jong, O. ve Talanquer, V. (2015). Why is it relevant to learn the big Ideas in chemistry at school? In Relevant Chemistry Education (pp. 11-31). SensePublishers.

Demircioğlu, G., Tütüncü, G. ve Demircioğlu, H. (2016). Lise 10. sınıf öğrencilerinin gazlar konusuna yönelik anlama düzeyleri ve belirlenen alternatif fikirler. Eğitim ve Öğretim Araştırmaları Dergisi, 5(3), 62-70. 
Doymuş, K., Canpolat, N., Bayrakçeken, S. ve Gürses, A. (1998). Üniversite kimya bölümü öğrencilerinin bazı kimya kavramlarını anlama düzeyleri. III. Ulusal Fen Bilimleri Eğitimi Sempozyumu, KTÜ Fatih Eğitim Fakültesi, Trabzon.

Fassoulopoulos, G., Kariotoglou, P. ve Koumaras, P. (2003). Consistent and inconsistent pupils' reasoning about intensive quantities: The case of density and pressure. Research in Science Education, 33, 71-87.

Gabel, D. (1999). Improving teaching and learning through chemistry education research: A look to the future. J. Chem. Educ, 76(4), 548-554.

Gegios, T., Salta, K. ve Koinis, S. (2017). Investigating high-school chemical kinetics: the Greek chemistry textbook and students' difficulties. Chemistry Education Research and Practice, 18(1), 151-168.

Gettys, W. E. Keller, F. J., ve Skove, M. J. (1995). Fizik 1. İstanbul: Literatür yayıncılık.

Gillette, G. ve Sanger, M. J. (2014). Analysing the distribution of questions in the gas law chapters of secondary and introductory college chemistry textbooks from the United States. Chemistry Education Research and Practice, 15(4), 787-799.

Hacioglu, Y., Durukan, U. G. ve Cigdem, S. A. H. I. (2016). What do science teacher candidates know about measuring instruments and units? Eurasian Journal of Educational Research, 16(64), 287-306.

Jacobson, M. Z. (2005). Fundamentals of atmospheric modeling (Second Edition). Cambridge university press, UK.

Karasar, N. (2012). Bilimsel araştırma yöntemi (24. Baskı). Ankara: Nobel Yayın Dağıtım

Kariotoglou, P. ve Psillos, D. (1993). Pupils' pressure models and their implications for instruction. Research in Science ve Technological Education, 11(1), 95-108.

Koç, Y. (2014). Fen eğitimi öğrencilerinin gazların dağıımını mikro boyutta anlama düzeyleri. $e$ kafkas eğitim araştırmaları dergisi, 1(1), 40-48.

Leite, L. ve Afonso, A. (2004). Forms of reasoning used by prospective physical sciences teachers when explaining and predicting natural phenomena: the case of air pressure. Canadian Journal of Math, Science ve Technology Education, 4(2), 169-191.

Lin H. S. Cheng H. J. ve Lawrenz F., (2000), The assessment of students and teachers' understanding of gas laws. Journal of Chemical Education, 77(2), 235-238.

Mandrikas, A. Skordoulis, C., ve Halkia, K. (2013). Pre-service elementary teachers' conceptions about wind. International Journal of Science Education, 35(11), 1902-1924.

Mas, C. J. Perez, J. H., ve Harris, H. H. (1987). Parallels between adolescents' conception of gases and the history of chemistry. Journal of Chemical Education, 64(7), 616- 618.

Mortimer, C. E. (1979). Chemistry-A Conceptual Approach, 4th ed. New York: D. Van Nostrand Co.

Nakiboğlu, C. ve Özkılıç-Arık, R. (2006). 4. Sınıf öğrencilerinin "gazlar" ile ilgili kavram yanılgılarının vdiyagramı kullanılarak belirlenmesi. Yeditepe Üniversitesi Eğitim Fakültesi Dergisi, 2(1), 31-46.

Nakiboğlu, C. ve Poyraz, E. H. (2004). An analysis of Turkish high school chemistry textbooks' questions related to "gas laws" according to Bloom's taxonomy. International Aegean Physical Chemistry Days, 7-10 October 2004.

Nakiboğlu, C. ve Yıldırır, H. E. (2011). Analysis of Turkish high school chemistry textbooks and teacher-generated questions about gas laws. International Journal of Science and Mathematics Education, 9(5), 1047-1071.

Nas, S. E. ve Çepni, S. (2016). Rehber materyallerin öğrencilerin olayları nedenleri ile açıklamaları üzerine etkisi: "Madde ve ısı" örneği. Alan Eğitimi Araştırmaları Dergisi, 2(1), 27-42.

Nelson, B. D., Aron, R. H. ve Francek, M. A. (1992). Clarification of selected misconceptions in physical geography. Journal of Geography, 91(2), 76-80.

Novick, S. ve Nussbaum, J. (1978) Junior high school pupils' understanding of the particulate nature of matter: An interview study. Science Education, 62, 273-281. 
Nurrenbern, S. C. ve Pickering, M. (1987). Concept learning versus problem solving: Is there a difference? J. Chem. Educ, 64(6), 508-510.

Önder, ì. ve Beşoluk, ş. (2010). Düzenlenmiş iki faktörlü çalışma süreci ölçeği'nin (R-SPQ-2F) Türkçeye uyarlanması. Eğitim ve Bilim, 35(157), 55-67.

Önen, F. (2005). Illköğretimde basınç konusunda öğrencilerin sahip olduğu kavram yanılgılarının yapılandırmacı yaklaşım ile giderilmesi. Yüksek Lisans Tezi, Marmara Üniversitesi, Eğitim Bilimleri Enstitüsü, İstanbul.

Özmen, H., Ayas, A. ve Coştu, B. (2002). Fen bilgisi öğretmen adaylarının maddenin tanecikli yapısı hakkındaki anlama seviyelerinin ve yanılgılarının belirlenmesi. Kuram ve Uygulamada Ĕgitim Bilimleri, 2(2), 507-529.

Pabuçcu, A. (2016). Fen bilgisi öğretmen adaylarının gaz basıncıyla ilgili bilgilerini günlük hayatla ilişkilendirebilme seviyeleri. Turkiye Kimya Dernegi Dergisi, Kisim C: Kimya Egitimi, 1(2), 1-24.

Papadimitriou, V. ve Londridou, P. (2001). A cross-age study of pupils' conceptions concerning the movement of air masses in the Troposphere. Proceedings of the 1st IOSTE Symposium of Southern Europe Science and Technology Education: Preparing Future Citizens, Paralimni, Cyprus, April 29-May 2, 2001, (pp. 358-368).

Pidwirny, M. (2016). Understanding Physical Geography (Chapter 7). Our Planet Earth Publishing, Canada.

Polito, E., Tanner, K. D. ve Monteverdi, J. P. (2008). Assessing middle school and college students' conceptions about tornadoes and other weather phenomena. In Proceedings of the 24th Conference on Severe Local Storms (pp. 26-30).

Psillos, D., ve Kariotoglou, P. (1999). Teaching fluids: Intended knowledge and students' actual conceptual evolution. International Journal of Science Education, 21(1), 17-38.

Raghavan, K., Sartoris, M. L. ve Glaser, R. (1998). Why does it go up? The impact of the MARS curriculum as revealed through changes in student explanations of a helium balloon. Journal of Research in Science Teaching, 35(5), 547-567.

Sadıç, A. (2017). Açık hava basıncı konusunun öğretiminde kullanılabilecek örnek tahmin-gözlemaçıklama etkinlikleri. Journal of Inquiry Based Activities, 6(2), 63-79.

Şahin, C. (2001). Türkiye' de coğrafya öğretimi. Ankara: Gündüz Eğitim ve Yayınclık.

Şahin, Ç. ve Çepni, S. (2012). 5E öğretim modeline dayalı öğretimin öğrencilerin gaz basıncı ile ilgili kavramsal anlamalarına etkisi. Necatibey Eğitim Fakültesi Elektronik Fen ve Matematik Eğitimi Dergisi, 6(1), 220-264.

Savec, V. F., Sajovic, I. ve Wissiak Grm, K. S. (2009). Action research to promote the formation of linkages by chemistry students between the macro, submicro, and symbolic representational levels. Multiple representations in chemical education, 309-331.

Sere, M. G. (1982). A study of some frameworks used by pupils aged 11 to 13 years in the interpretation of air pressure. International Journal of Science Education, 4(3), 299-309.

Stavy, R. (1988). Children's conceptions of gas. International Journal of Science Education, 10(5), 553560.

Taylor, N. ve Lucas, K.B. (2000). Implementing and evaluating a sequence of instruction on gaseous pressure with pre-service primary school student teachers. Australian Science Teachers Journal, 46(4), 9-34.

Treagust, D. F. ve Chandrasegaran, A. L. (2009). The efficacy of an alternative instructional programme designed to enhance secondary students' competence in the triplet relationship. Multiple representations in chemical education, models and modeling in science education (Vol. 4, pp. 151-168). Dordrecht, The Netherlands: Springer.

Tytler, R. (1998). The nature of students' informal science conceptions. International Journal of Science Education, 20(8), 901-927.

Wallace, J. M. ve Hobbs, P. V. (2006). Atmospheric science: an introductory survey (Vol. 92). Academic press. 
Wiebe, R. ve Stinner, A. (2010). Using story to help student understanding of gas behavior. Interchange, 41(4), 347-361.

Yalçınkaya, E. ve Boz, Y. (2015). The effect of case-based instruction on 10th grade students' understanding of gas concepts. Chemistry Education Research and Practice, 16, 104-120.

Yıldırım, N., Kurt, S. ve Ayas, A. (2011). The effect of the worksheets on students achievement in teaching the subject the factors of effects on chemical equilibrium. Journal of Turkish Science Education, 8(3), 44-58. 


\section{Extended Summary}

\section{Introduction}

One of the aims of science teaching is to involve individuals in decision-making and problem-solving processes about science-related events (Leite and Afonso, 2004). This requires individuals to be able to understand the science and explain the related situations or events. However, many researches indicate that students have difficulties in understanding and explaining the phenomena related to science (Doymus, Canpolat, Bayrakçeken and Gürses, 1998, Birinci-Konur and Ayas, 2010, Demircioğlu, Tütüncü and Demircioğlu, 2016). One of the main reasons of this problem may be explaining and teaching science in a complex and abstract way (Gabel, 1999). In order for learners to perform meaningful learning, we first need to know what they know and how they construct scientific knowledge (Lin, Cheng and Lawrenz, 2000). This will only be possible by determining how students perform their conceptual learning in their teaching activities. Meanwhile, teachers should organize their learning environments by taking into consideration the macro, submicro and symbolic structure of science concepts (Barke, Hazari and Yitbarek, 2009). Many studies have found that these dimensions are not considered together for meaningful learning despite the fact that teachers benefit from these dimensions to some extend while teaching (Savec, Sajovic and Wissiak Grm, 2009, Treagust and Chandrasegaran, 2009, Koç, 2014). This makes it difficult for students to relate many unrelated pieces of information which hinders meaningful learning (Gabel, 1999) and makes it difficult for learners to understand science related events and daily life problems. Questions based on calculations and that require mathematical operations are generally used while determining students' conceptual understanding (Lin, Cheng and Lawrenz, 2000). This makes students to concentrate on mathematical operations rather than understanding concepts precisely (Bodner, 1991; Gabel, 1999). De Berg (1995) emphasizes that addiction to questions requiring mathematical operations will decrease with the use of explanatory questions, and which will support conceptual learning. Many concepts in science are important in their discipline as well as in other disciplines. The atmospheric pressure is one of these interdisciplinary concepts and is a phenomenon we often encounter in everyday life. To understand the atmospheric pressure and the variables affecting it, firstly students should know basic concepts such as mass, force, weight, pressure, volume, gravitational force, heat, temperature, specific heat capacity, molar mass, area, humidity, altitude, acceleration, moment, fluidity, concentration and density, and missing or incorrect knowledge in these concepts cause difficulties in understanding the atmospheric pressure (Basca and Grotzer, 2001, Kariotoglou and Psillos, 1993, Önen, 2005, Psillos and Kariotoglou, 1999, Raghavan, Sartoris, and Glaser, 1998, Sere , 1982; Tytler, 1998). In addition, atmospheric pressure and the factors affecting it are explained much less in the textbooks than the subjects related to pressure of solids, liquids and gases in closed systems. Moreover, there are very few explanations in the textbooks regarding the exact and clear definition of the atmospheric pressure and its relation with altitude, temperature and humidity. Therefore, in this study, it was aimed to determine high school students' and teacher candidates' explanations of atmospheric pressure, factors affecting it and related daily life problems and to what extend explanations of high school students and teacher candidates differ.

\section{Method}

The research was carried out with a survey method. In total 200 participants participated to the study; 70 of which were senior high school students, 77 were senior science teacher candidates, 23 were senior chemistry teacher candidates and 30 were senior physics teacher candidates. In the study, a form with one open-ended and eight two-tiered questions was used as data collection tool (see Appendix 1). The questions were about definition of atmospheric pressure, factors affecting it, and daily life problems related to atmospheric pressure. In two-tiered questions, students were asked to mark one of the three options given in the first part of the question, and in the second part they were asked to explain why they have chosen that option. The analyses of the data were carried out by the help of categories provided in the studies of Nas and Çepni (2016) and Abraham, Grzybowski, Renner and Marek (1992). The categories are "full understanding (FU), partial understanding (PU), partial understanding with misunderstanding (PUM), misunderstanding (M) and not understanding (NU)". In the analysis of the twotiered questions, first the choices of students were categorized as Right Choice (RC), Wrong Choice (WC) and Empty (E). And in the second part where students provided their reasons of choice, students' answers were categorized as "full understanding, partial understanding, partial understanding with 
misunderstanding, misunderstanding and not understanding". Participants' responses were analyzed separately by two researchers. In case of disagreement, researchers made a common decision. Inter rater reliability was .87 .

\section{Results}

The responses of the participants to the question regarding definition of atmospheric pressure mainly fell into the category of PUM with a total of 69 people and in category NU with 55 people. In the second question (How does atmospheric pressure changes with the increase in humidity?), only one chemistry teacher candidate's explanation fell into RC-FU category. Participants generally chose the wrong answer and regardless of their level of education they seem to have many misconceptions in this issue. In question regarding change in atmospheric pressure with altitude, majority of the participants marked the right option, and their answers are mostly gathered in RC-NU and RC-PU categories. On the other hand, large majority of participants marked the wrong option in the question in which relationship between atmospheric pressure and temperature were questioned. In this question answers mostly fell into WC-NU category. In the fifth question a case related to atmospheric pressure and altitude was provided. In this question, responses mainly fell into RC-FU category. In the next question participants' responses mostly gathered in RC-PU, RC-FU and RC-NU categories. In the seventh question a case related to atmospheric pressure and temperature was provided. It was determined that participants' responses were mostly collected in categories WC-NU, WC-M and WC-PUM. In the next question, where the effect of temperature and humidity on atmospheric pressure was investigated, participants' answers mostly collected in the categories WC-NU and RC-NU. Most of the participants left the last question blank or chose the wrong option. Participants' answers mostly fell into categories WC-PU, E-NU and WC-NU.

\section{Discussion and Conclusion}

The results of the study showed that participants were often inadequate to explain the concept of atmospheric pressure, the factors that affected it and the associated events, and there were significant and numerous mistakes in participants descriptions that are in conflict with scientific knowledge. In addition, in terms of education levels, there were no serious differences in correct answer rates of the questions. These results may arise from; inadequate information provided in the textbooks about atmospheric pressure, the features of the atmospheric pressure, gases in closed systems and their differences are not given adequately, the problems/questions that are used for teaching or evaluation in the courses/textbooks are generally superficial and mathematical operations oriented, the courses are not designed with multidisciplinary point of view, just definitions of the concepts are generally provided and links between concepts are not provided, etc. Results of the study also showed that when the number of variables related to an event increases, the ratio of correct explanations decreases. However, scientific explanations of daily life events are often multidimensional, multivariate and interdisciplinary in nature. Therefore, it is not possible to explain science events well and correctly with a onedimensional point of view. If teaching of science is carried out without considering the multidimensionality and interdisciplinary nature and with giving just definition of concepts and with focusing mainly on mathematical operations, it is an expected outcome that students will have difficulty in describing the events they meet. One of the important outcomes of this study is that as level of education increased the ratio of correct answers did not increased significantly. Although generalization of this result is limited to participants of this study, it does not display a promising picture of the future. For this reason, it is suggested to all stakeholders that results of this and similar studies should be considered while writing textbooks and planning of educational activities. 


\section{EK1}

\section{Sorular}

1. Açık hava basıncını tanımlayınız.

2. Havadaki nem oranı arttığında açık hava basıncı nasıl değişir?
A) Artar
B) Değişmez
C) Azalır

Cevabınızın neden(ler)ini açıklayınız

3. Deniz seviyesinden yukarılara çıktıkça açık hava basıncı nasıl değişir?
A) Artar
B) Değişmez
C) Azalır

Cevabınızın neden(ler)ini açıklayınız

4. Sıcaklık arttıkça açık hava basıncı nasıl değişir?
A) Artar
B) Değişmez
C) Azalır

Cevabınızın neden(ler)ini açıklayınız

5. Bir uçak 1500 m yüksekte uçmakta iken teknik bir arıza nedeniyle kapılarından bir tanesinin açıldığını düşünürsek aşağıdakilerden hangisi gerçekleşir?
A) Uçağın içinden dışarıya doğru şiddetli bir hava akışı olur
B) Uçağın dışından içine doğru şiddetli bir hava akışı olur.
C) Uçağın dışından içeriye doğru ve uçağın içinden dışarıya doğru iki yönlü hava akışı olur.
Cevabınızın neden(ler)ini açıklayınız

6. Çok yüksek bir dağa tırmanmakta olan bir dağcı zirveye yaklaştıkça aşağıdakilerden hangisi olabilir? Cevabınııın neden(ler)ini açıklayınız
A) Nefes almada bir sorun yaşamaz
B) Çok zor nefes alır
C) Çok kolay nefes alır

7. Akşam vakti deniz kıyısında yürürken hafifçe esen rüzgarın yönü için ne söylersiniz. Cevabınızın neden(ler)ini açıklayınız
A) Karadan denize doğru eser
B) Denizden karaya doğru eser
C) Her iki yöne doğru eser

8. Aşağıdaki ortamlardan hangisinde nefes almak daha kolaydır?
A)Sıcak ve nemli bir havada
B) Serin ve kuru bir havada
C) Sıcak ve kuru bir havada
D) Serin ve nemli bir havada
Cevabınızın neden(ler)ini açıklayınız

9. Üflenerek biraz şişirilip ağzı iple bağlanmış elastik bir balon, bulunduğu ortamdan alınarak,

I. Aynı basınçta, daha soğuk

II. Aynı sıcaklıkta, yükseltisi daha fazla

III. Aynı sıcaklıkta, havası boşaltıımış

ortamlardan hangisine konulduğunda, balonun hacminin artması beklenir?

Cevabınızın neden(ler)ini açıklayınız. 